This is the accepted manuscript of the article, which has been published in

Global Constitutionalism. 2019. https://doi.org/10.1017/S2045381719000133

\title{
'Shunning' and 'Seeking' membership: rethinking citizenship regimes in the European constitutional space
}

\author{
Jo Shaw \\ jo.shaw@ed.ac.uk orcid.org/0000-0002-4423-2984
}

Biography: Jo Shaw holds the Salvesen Chair of European Institutions at the University of Edinburgh and a part-time professorship in the New Social Research Programme at Tampere University. From 2009-2014 she directed a European Research Council programme on Citizenship in South East Europe (CITSEE) and she now holds (20182020) a Leverhulme Major Research Fellowship for a study of citizenship regimes.

\begin{abstract}
This article explores parallels between the 'shunning' and 'seeking' of membership of the EU in the context of Brexit and stalled enlargement in south east Europe, via a focus on the partial, fragmentary and contested governance of citizenship. The case studies place Union citizenship into a wider political and socio-economic context, demonstrating its central importance as an enabler of personal freedom. At the same time, they highlight how the denial or removal of Union citizenship can engender individual strategies to recover lost or denied benefits. From the analysis, parallels emerge between Union citizenship and national citizenship; both offer a promise of equality, but a reality of differentiation and inequality. At the same time, by delving deep into the case studies, it proves possible to illuminate the complex and often 'messy' constitutional edifice of the European Union, involving sometimes contradictory processes of Europeanisation and de-Europeanisation affecting citizenship regimes at all levels.
\end{abstract}

Keywords: Brexit, enlargement, Europeanisation, European Union, citizenship

\section{Acknowledgements}

The support of the Marie Curie Co-Fund EURIAS Programme (PCOFUND-GA2013609400) and the Helsinki Collegium for Advanced Studies (where I was resident in 2017-2018) for the preparation of an earlier version of this paper are acknowledged with thanks. Subsequent versions were supported by the Leverhulme Major Research Fellowship (MRF-2016-190) on Building Citizenship Regimes: a global perspective. The article builds on a number of previous texts written on Brexit, Union citizenship and citizenship in south east Europe, in the latter case drawing on research conducted within the framework of CITSEE: The Europeanisation of Citizenship in the Successor States of the Former Yugoslavia, ERC Grant 230239. I am also grateful to Lorenzo Piccoli and Jean-Thomas Arrighi for pushing me on the original idea for a comparison between North West and South East Europe, to Jelena Džankić and Païvi Neuvonen for comments on an early draft, and to my colleagues in New Social Research at Tampere University for encouragement to pick up the project again when it seemed to be flagging. Two anonymous reviewers for the journal also provided very useful reflections. However, I am most grateful to my colleague Niamh Nic Shuibhne for comments on two drafts, latterly on an almost final draft. Remaining infelicities and errors are mine alone. 


\section{Introduction: the shunners and the seekers of European constitutional order}

Since the 1950s, the European Union (EU) has emerged as a semi-constitutionalised non-state polity with institutions endowed with legislative powers and an independent Court of Justice (CJEU), mandating the sharing of some areas of sovereignty amongst its Member States. ${ }^{1}$ In terms of both its economic and its civilian power, it casts an extensive shadow over the states in its neighbourhood, both those that seek membership and those that, for various reasons, shun it. ${ }^{2}$

In the north west corner of Europe, after many years of internal political strife relating to its EU membership, the United Kingdom decided to hold an in/out referendum. This decision reflected years of contested EU policy within the Conservative Party (between pro- and anti-European wings) and the dramatic rise of the populist anti-EU UK Independence Party (UKIP). In June 2016, after a problematic campaign in which 'immigration' (which also encompassed EU free movement) became an increasingly salient policy issue, the electorate of the UK decided, by a margin of $52 \%$ to $48 \%$, that the UK should leave the EU (i.e. 'Brexit').

This has launched a process that may take a decade or more to complete and which will be likely to have effects that are felt for many decades to come, certainly by those persons directly implicated by the decision (i.e. mobile UK and EU27 citizens plus their families) and quite probably in respect of the development of the economy and the society as a whole. ${ }^{3}$ Many fear that the effects of Brexit will be negative in terms of both economic growth and social cohesion. The process has both formal and informal dimensions of adjustment. While Article 50 of the Treaty on European Union ('TEU') is the legal basis for any withdrawal agreement, any future agreement between the EU (and its Member States) will need to be concluded on the basis of the EU Treaty provisions on relations with third countries. The impact of Brexit will extend well beyond legal formalities. All Member States and their citizens will inevitably be affected by the reduction in the size of the EU, the removal of a major economy from the single market and the EU budget, the departure of an important power from the negotiating table, and the symbolic impact on the idea of integration brought about by a contraction of territory and numbers of citizens. ${ }^{4}$

In the south east corner of Europe, after the break-up of the Socialist Federal Republic of Yugoslavia (SFRY) in the 1990s, seven new states eventually emerged where once there was one, each with its own national citizenship regime. First came Slovenia,

\footnotetext{
1 See most recently, in the context of the interpretation of Article 50 TEU, Case C-621/18 Wightman and others v. Secretary of State for Exiting the European Union ECLI:EU:C:2018:999.

2 T Börzel, 'European Governance - Negotiation and Competition in the Shadow of Hierarchy', (2010) 48 Journal of Common Market Studies 191-219.

3 J Shaw, 'Citizenship and free movement in a changing EU: Navigating an archipelago of contradictions', in B Martill and U Staiger (eds.), Brexit and beyond: Rethinking the future of Europe (UCL Press, London, 2018) 260-265.

$4 \quad$ U Staiger and B Martill, 'Rethinking the futures of Europe', in Martill and Staiger, above n3.
} 
Croatia, Bosnia and Herzogovina, Macedonia ${ }^{5}$ and the Federal Republic of Yugoslavia (FRY) from 1992, with Montenegro and Serbia eventually emerging in 2006 as separate states from FRY / the State Union of Serbia and Montenegro, with Montenegro's expressed wish to be independent. Finally, Kosovo gained independence in 2008. To give an example of the impact of multiple changes at the state level, a citizen of Serbia or Montenegro born before 1991, who never left their hometown, will have been in their lifetime a citizen of four different states, even without taking any possible dual citizenships (e.g. by descent) into account.

The 1990s saw major conflict and violence in the region, for complex reasons that included ethnic tensions and the role of political elites with expansionist ambitions. Several of the new states remain weak and unconsolidated both internally and externally, including Bosnia and Herzegovina, what is now North Macedonia and Kosovo. Democratic backsliding and corruption are problems in many of the states. Despite general political will on all sides pointing strongly in the direction of a European future, the prospects that all these new states could become Member States of the European Union within a few years are low. ${ }^{6}$ Since the accession of Slovenia in 2004 and Croatia in 2013 under Article 49 TEU, the enlargement process has stalled, leaving the other five new states, plus neighbouring Albania, and their citizens, 'out in the cold'. This is the region that the EU terms the 'Western Balkans'. All of its land borders abut EU Member States.

At first sight, there seems little that these two cases of shunning and seeking the membership of a supranational organisation have in common. The main aim of this article is to push back against this assumption, and to identify what type of analytical framework, drawing mainly on legal, political and constitutional scholarship, is useful for engaging in a comparison of similarities and differences. As to the purpose of the 'push back', the argument is developed that this juxtaposition of two ostensibly contrasting 'European stories ${ }^{7}$ can illuminate some of the most important dynamics of the complex and differentiated 'euro-polity', with its multilevel and incomplete constitutional framework, and can help us reconsider questions about what it means to be 'European'. As to the framework for the comparison, this draws upon a critique of how Europeanisation, de-Europeanisation and indeed re-Europeanisation play out within the EU's constitutional framework using a case study of EU-level and national citizenship regimes viewed from the perspective of Brexit and stalled enlargement.

\section{The consequences of Brexit and stalled enlargement in a messy constitutional order}

Both internally, and in its relationships with 'the outside' and 'outsiders', the European Union operates with a messy multi-layered constitutional structure and more complex sets of relationships than is often appreciated by those whose classic starting point is the

\footnotetext{
5 At the insistence of Greece because of concerns around its own region of Macedonia, on independence the country was formally known as the 'Former Yugoslav Republic of Macedonia'. The country has recently altered its name after the Prespo agreement with Greece and is now called Northern Macedonia.

$6 \quad$ For a review of EU's relations with the Western Balkans see T Vogel, Out of Focus: the EU's Relations with the Western Balkans, Blog, Heinrich Böll Foundation, 9 October 2018, available at <https://eu.boell.org/en/2018/10/09/out-focus-eus-relations-western-balkans>.

$7 \quad$ J Lacroix and K Nicolaïdis (eds), European Stories: Intellectual Debates on Europe in National Contexts (Oxford University Press, Oxford, 2010).
} 
uniformity and supremacy of EU law vis-à-vis national law and a binary notion that a given state is either inside, or outside, the EU. ${ }^{8}$ Analysis of the euro-polity through the prism of these two peripheries, in relation to the manner in which they engage with 'the mainstream', raises questions not only about the constitutional framework of the Union itself and those of the Member States, but also about those of the states shunning and seeking membership (however successful or unsuccessful they are in their respective strategies). It tells an important story about Europeanisation, de-Europeanisation and potential re-Europeanisation, concepts that should be understood in a broad sociocultural sense that encompasses not only the enforceable legal obligations of EU membership, but also other issues of 'fit' (or lack of it) between the EU, national and subnational levels of governance as well as broader societal dynamics.

There are many common elements and areas of symmetry between the two cases, although they involve differing starting points and processes of change, not to mention contrasting political, social and economic circumstances. Catherine Baker argues that 'the UK and Yugoslavia represent two comparable multinational states with severe regional inequalities, and unresolved histories of state and non-state political violence.’9 Federal Yugoslavia disintegrated, pushing most of its constituent states from the front of the 'queue' for integration with the then European Communities, where it sat until 1991 with a unique Cooperation Agreement and serious prospects of an Association Agreement, ${ }^{10}$ to the back. Brexit, meanwhile, is placing intense pressure upon internal boundaries and territorial governance within the UK, ${ }^{11}$ especially as regards the status of Northern Ireland and (perhaps less urgently, but none the less significantly) Scotland. It has been argued that Brexit could precipitate the break-up of the Union. ${ }^{12}$ Furthermore, the processes themselves are less sharp or simple than they appear at first sight, and the outcomes less clear. The UK wishes to leave the EU, although close observers will have spotted that leaving is complicated and any departure may not result in the sharp break that many Leave campaigners have argued for enthusiastically since the vote. ${ }^{13}$ The new states of south east Europe and Albania wish to accede to the EU, but are held at bay for a combination of political and economic reasons, many of which are outside their (citizens' and governments') control, and relate to a reassertion of control in the context of enlargement policies by the existing Member States. ${ }^{14}$ In sum,

$8 \quad$ It should be noted that this binary division, and the importance of national sovereignty in this context, dominates the CJEU's judgment in Wightman, see $\mathrm{n} 1$.

$9 \quad$ C Baker, Race and the Yugoslav Region (Manchester University Press, Manchester 2018) 183. Others have argued for parallels between the disintegration of Yugoslavia and the crisis of integration that the EU faces more generally: J Becker, 'In the Yugoslav Mirror: The EU Disintegration Crisis’, (2017) 14 Globalizations 840-850. B Zaccaria, The EEC’s Yugoslav Policy in Cold War Europe, 1968-1980 (Palgrave, London, 2016); I Obadic, A troubled relationship: Yugoslavia and the European Economic Community in détente’, (2014) 21 European Review of History: Revue europeenne d'histoire 329-348. T Mullen, 'Brexit and the territorial governance of the United Kingdom', (2019) Contemporary Social Science, DOI: 10.1080/21582041.2018.1563802.

12 D Wincott, 'Brexit and the State of the United Kingdom', in P Diamond, P Nedergaard and B Rosamond (eds), The Routledge Handbook of the Politics of Brexit (Routledge, London, 2018) 15-26; B Jessop, 'The Organic Crisis of the British State: Putting Brexit in its Place', (2017) 14 Globalizations 133-141.

13 A Gamble, 'Taking back control: the political implications of Brexit', (2018) 25 Journal of European Public Policy 1215-1232. 
Brexit and stalled enlargement could both be dubbed cases of 'troubled (non)membership’ (adapting a term coined by Carlos Closa ${ }^{15}$ ).

This is a broad and potentially open-ended topic, so this article narrows the focus by exploring the parallels between the two cases of Brexit and (stalled) enlargement in one specific area: that of citizenship. Assessing similar questions in relation to what they term the 'territorial rescaling' of citizenship, Jean-Thomas Arrighi and Dejan Stjepanović point out that 'the problem is thus not so much that borders migrate, but that they do so over people.' 16 These impacts demand close study.

With its legal, political and identitarian dimensions, ${ }^{17}$ the transformation of citizenship in the European constitutional space offers an ideal test case through which to explore the processes of integration and disintegration which are occurring across the north western and south eastern borders of the EU. So many different aspects of collective and individual life are touched by citizenship.

The focus is on both Union citizenship at the supranational level and the national citizenship regimes of Member States and putative and departing Member States, as well as on the relationship between the 'levels'. The idea of a common Union citizenship, attaching solely to those who are the nationals of the Member States and drawing strength from related international sources of law such as the European Convention on Human Rights and the European Convention on Nationality, is arguably one of the core constitutional pillars of the European Union. Like the Union itself, though, Union citizenship is messy, incomplete and contested, especially as regards its impacts on domestic citizenship regimes. Union citizenship is said, by the European Court of Justice, to be 'destined to be the fundamental status of the nationals of the Member States', ${ }^{18}$ but in many respects this statement seems to be judicial flourish and jurisprudential innovation, rather than rigorous textual interpretation of the treaties, related legal sources and prior case law. ${ }^{19}$ What is important is that 'citizenship' (and citizenship regimes), especially when explored through conceptual rather than just legal lenses, can have symbolic and ideational value extending well beyond the institutional apparatus. $^{20}$

At both the practical and the ideational levels, Brexit and (stalled) enlargement impact in important ways upon the partial, fragmentary and contested multi-level governance of citizenship in Europe: as a result of geo-political changes/non-changes in the dimensions of the EU (the fraught process of Brexit and what is, for now, a stalled enlargement process in south east Europe), certain groups of national citizens may remain, or become, or cease to be, or never become Union citizens; or they may lose or

15 C Closa (ed), Secession from a Member State and Withdrawal from the European Union (Cambridge University Press, Cambridge, 2018).

16 J-T Arrighi and D Stjepanović, 'Introduction: The Rescaling of Territory and Citizenship in Europe, (2019) 18 Ethnopolitics DOI: 10.1080/17449057.2019.1585087 at 3. A Wiener, 'Making Sense of the New Geography of Citizenship: Fragmented Citizenship in the European Union’ (1997) 26 Theory and Society 529-60.

18 Case C-184/99 Grzelczyk ECLI:EU:C:2001:458, para 31.

$19 \quad$ F Strumia, 'European Citizenship and Transnational Rights: Chronicles of a Troubled Narrative', in D Thym (ed), Questioning EU Citizenship: judges and the Limits of Free Movement and Solidarity in the EU (Hart, Oxford, 2017) 149-167. 
gain the rights and privileges of Union citizenship through residence in another state, which becomes or ceases to be an EU Member State. Conversely, they may become, or remain, third country nationals subject to a body of laws stemming partly from the EU and partly from the Member States, in this area of shared competence. As to their status as national citizens of one or more states, this is thrown into high relief by the pressures on rights holding and rights exercising that Brexit and stalled enlargement give rise. Since neither case to be examined evinces a smooth pathway to exit/entry, this intensifies pressures on the citizenship regimes of all the states involved (including the remaining Member States) across areas of domestic policy that are not those most obviously influenced by EU law, including the norms governing the acquisition and loss of citizenship and consequent 'citizenship practices' of affected individuals and groups. In the case of Brexit, levels of anxiety about possible outcomes including 'no deal' are high. ${ }^{21}$ In the case of south east Europe, citizens are left more isolated because they do not enjoy the benefits of Union citizenship, and disillusionment with political authorities both domestically and in the EU is high. ${ }^{22}$

The two cases are different, of course, because in one Union citizenship has not so far been conferred on the national citizens and indeed may never be (i.e., stalled enlargement), but in the other it seems most likely to be removed having once been in place (i.e., withdrawal from the EU). But that identifies another parallel between the two cases. The process and direction of travel are different, but the outcomes could end up being the same. Both citizenries would be on the outside, as would both territories, which likewise would mean that those who retain Union citizenship (i.e., the citizens of the EU27) would not benefit from this status when in those countries. They themselves would be third country nationals in respect of those newly, or still, third countries.

The next section of the article will link these preliminary descriptive observations about the 'citizenship consequences' of Brexit and stalled enlargement to a wider framework encompassing the complex and messy multi-level framework of the Euro-polity (Section III). Section IV explores the analytical possibilities of combining a focus on rethinking citizenship with a focus on the concepts and practices of de/Europeanisation in the context of regional dis/integration, highlighting the differential impacts of legal and institutional changes as well as the broader symbolic questions about 'who belongs'. This framing produces a range of tools for assessing the impacts of change and no change in relation to withdrawal from or accession to the European Union, which can be applied when studying Brexit (Section V) and (stalled) enlargement (Section VI). These sections will show, in practice, how citizenship governance is both contested and fragmented within the European constitutional space, where we can see a Europe of not one, but many citizenships. Section VII provides a brief conclusion by linking the case studies of citizenship governance back to the broader questions of constitutionalism and constitutionalisation in the euro-polity.

\section{Citizenship governance in Europe's contested constitutional space}

\footnotetext{
$21 \quad$ T Guma and R Dafydd Jones, “"Where are we going to go now?” European Union migrants' experiences of hostility, anxiety, and (non-)belonging during Brexit’ (2019) 25 Population, Space and Place, DOI: 10.1002/psp.2198.

22 R Belloni, 'The European Union Blowback? Euroscepticism and its Consequences in the Western Balkans’, (2016) 10 Journal of Intervention and Statebuilding 530-547.
} 
While the power to set the rules on acquisition and loss of citizenship is prima facie a matter of national sovereign prerogative, this does not mean that these rules are not influenced by factors such as migration flows, the measures taken by other countries and the activities of supranational and international organisations. For some decades, multiple sites of citizenship governance within Europe have laid claim to authority and legitimacy in relation to the allocation of citizenship rights and, to a rather lesser extent, the allegiance of citizens, at the subnational, national, supranational and international levels. ${ }^{23}$ This process of normative fragmentation continues as the EU develops further and as restive subnational units, e.g. in Spain and the UK, request and exercise additional powers which determine many of the substantive rights of citizenship, if not the actual scope of national citizenship. It extends across all the interrelated domains of citizenship as a membership status, including the civic, private, political, economic, social and cultural/identitarian domains.

In the sphere of citizenship, regional integration EU-style began with legally enforceable but not unconditional freedom of movement for persons, buttressed by principles of mutual recognition, guarantees of non-discrimination on grounds of nationality, and legislative measures taken to ensure a level playing field within a single market. The conditions and limits relate to a broad range of matters including public health, security and policy, employment in some parts of the public service, and some (more limited) options for protecting areas of national sovereignty such as culture, language and the welfare state. ${ }^{24}$ This complex network of provisions is underpinned by the role given to the CJEU to interpret and apply EU law, especially in response to references made by national courts seeking to clarify uncertainties. Taken as a whole, the measures relating to the free movement of persons on their own already have the potential to alter the boundaries of membership for individuals, by granting new rights whilst placing new restrictions on Member States by reference to market norms, leading to a dramatic rescaling of citizenship rights and practices.

A further step was taken with the formal recognition of a concept of 'citizenship of the Union' in the EU's formative Treaty of Maastricht in 1993. Measures relating to 'citizenship' are now to be found in the TEU, in the Treaty on the Functioning of the European Union (TFEU) and in other legal instruments such as Directive 2004/38, the so-called Citizens' Rights Directive. ${ }^{25}$ There is also a considerable - and not always entirely clear or consistent - body of case law from the CJEU. ${ }^{26}$ The existence of Union citizenship makes it clear that the UK is leaving, and the Western Balkan states are seeking to join, a constitutionalised political edifice which is more than simply a framework for (socio-)economic cooperation, even though the precise character of that 'citizenship figure' is not clear. ${ }^{27}$ Union citizenship brings the free moving EU citizen

\footnotetext{
23 R Bauböck, 'Citizenship and Collective Identities as Political Sources of Solidarity in the European Union', in K Banting and W Kymlicka, (eds), The strains of commitment: The political sources of solidarity in diverse societies (Oxford University Press, Oxford, 2017), 80 106. 
to the forefront of the EU's constitutional concerns, but those same legal structures make access to Union citizenship dependent upon being a national of a Member State. In that sense, Union citizenship continues to be derivative from an exercise of national sovereignty, which determines who are the national citizens. ${ }^{28}$ A modest framework of additional rights focused on free moving citizens has been grafted around the concept of Union citizenship, such as the right to vote in European Parliament and local elections on the basis of residence, and rights to consular protection when in third countries. They buttress the notion that the free moving Union citizen should be seen from the perspective of Member State laws as a 'second country' rather than 'third country' national. At the same time, the EU treaties also seem to offer little direct benefit to those citizens who do not exercise free movement rights, beyond what many see as the dubious privilege of being able to vote in European Parliament elections as an additional layer of democratic engagement beyond the state. ${ }^{29}$ This creates a scenario in which 'static' citizens could easily see themselves as victims, not beneficiaries, of the integration process and as second class Union citizens. Even though Union citizenship is additive (and indeed generally popular amongst the nationals of the Member States), it is not uniformly seen as positive across all sectors of society, or in all Member States. ${ }^{30}$ The political and identitarian dimensions of Union citizenship remain relatively weak, and given the limited role of the EU in relation to matters of redistribution (e.g., through taxation), its capacity to foster social cohesion is similarly limited.

At the same time as opening up internal borders, free movement has also been paired with a closure of the outer boundaries of the EU. These are the policies of so-called Fortress Europe, encompassing migration, asylum and border policies shared between the Member States and the EU which close off South-North and East-West migration from beyond the boundaries of the EU, turn the Mediterranean Sea into a graveyard and place what some Member States see as unwarranted burdens upon them, because of the inadequacies of burden-sharing processes in relation to refugee arrival and reception. ${ }^{31}$ Much of this is done in the name of protecting both national cultures and the viability of the national welfare state. ${ }^{32}$

Citizenship governance has become increasingly contested across the European political space. By the end of the 2010s, fraught centre-periphery dynamics regarding the trajectory of integration had become entrenched, not least in the wake of the 2004 and 2007 enlargements which led to an increased rate of labour mobility across the EU. ${ }^{33}$

L Orgad and J Lepoutre, Should EU citizenship be disentangled from member state nationality?, EUI Working Paper, 2019/24.

29 The right to vote in European Parliament elections was confirmed by the CJEU in Case C650/13 Delvigne ECLI:EU:C:2015:648. See S Vasilopoulou \& L Talving, 'Opportunity or threat? Public attitudes towards EU freedom of movement', (2019) 26 Journal of European Public Policy 805-823.

31 W Outhwaite, 'Migration Crisis and "Brexit”', in C Menjívar et al (eds), The Oxford Handbook of Migration Crises (Oxford University Press, Oxford, 2019), A Favell, 'Brexit: a requiem for the post-national society?', (2019) 9 Global Discourse, DOI:

10.1332/204378918X15453934506021.

32 C Cantat and P Rajaram, 'The Politics of Refugee Crisis in Hungary: B/ordering the Nation and Its Others', in Menjívar et al above n31.

33 B Glorius et al (eds) Mobility in Transition: Migration Patterns after EU Enlargement (Amsterdam University Press, Amsterdam, 2013), JSTOR, <www.jstor.org/stable/j.ctt46mwhx>; M Kahanec and M Pytliková, 'The economic impact of east-west migration on the European Union', (2017) 44 Empirica 407-433. 
South North migration also increased in the wake of the financial crisis at the end of the 2000s and of the recessions to which it gave rise. ${ }^{34}$ These dynamics have contributed to challenging certain assumptions about 'ever closer union' that earlier came to dominate much public discourse around the EU. Levels of contestation over processes of regional integration have generally remained highest at Europe's geographical edges. They have impacted upon the calculus of the socio-economic benefits of membership and on identity questions about 'who we are'. The value of free movement has been put in question, ${ }^{35}$ at the same time as Union citizenship's apparent 'lack of duties' has been raised as a problem. ${ }^{36}$

The same normative fragmentation that has offered the personal and market freedoms of free movement and mutual recognition, ${ }^{37}$ with Union citizenship operating also as a symbol for an emerging European political and constitutional space, ${ }^{38}$ has come to be contested across a number of dimensions. ${ }^{39}$ For example, questions have been raised about duties and relationships of solidarity, which take different forms across the multilevel framework of citizenship governance. ${ }^{40}$ Some fear that the EU principles of non-discrimination between states and citizens undermine equality within states, in relation to 'their' citizens. Union citizenship is designed to be additional to and not to replace national citizenship. This may be true at the individual level. However, at the collective level, Union citizenship arguably has the effect of hollowing out national citizenship regimes by creating new sites of privilege and disadvantage, which distort the domestic settlement or social contract. ${ }^{41}$ An explicitly nationalist line holds that EU membership 'necessarily weakens national citizenship, because it limits the democratic choices member states can make and prevents national governments from prioritising the welfare of their own citizens'. ${ }^{42}$ The same line of argument can be used to justify restricting the scope of Union citizenship by rejecting future enlargements on the grounds that it creates too much potential for intra-EU mobility. A claim around the immigration risks of the putative accession of Turkey to the EU was used in the Brexit referendum, even though such an enlargement is unlikely to happen even in the medium term. ${ }^{43}$ But when it comes to assessing such claims, it may sometimes be hard to determine where the line lies between policies to support the legitimate national foundations of the social contract, on the one hand, and welfare chauvinism, on the

$34 \quad$ JM Lafleur and M Stanek (eds), South-North Migration of EU Citizens in Times of Crisis (Springer International Publishing, Cham, 2017).

35 'Freedom of Movement under Attack: Is it worth defending as the core of EU citizenship?', Part II of R Bauböck (ed), Debating European Citizenship (Springer International Publishing, Cham, 2019).

36 'Should EU Citizenship be Duty-Free?', Part III of Bauböck above n35.

37 K Nicolaïdes, 'Mutual Recognition: Promise and Denial, from Sapiens to Brexit', (2017) 70 Current Legal Problems 1-40. J Shaw 'Citizenship: contrasting dynamics at the interface of integration and constitutionalism', in P Craig and G de Búrca (eds), The Evolution of EU Law (2nd edn, Oxford University Press, Oxford, 2011) 575-609; J Shaw, 'EU citizenship: still a fundamental status?', in Bauböck above n35 1-17. Vasiloupoulou and Talving above n30.

Bauböck, above n23; R Bellamy and J Lacey, 'Balancing the rights and duties of European and national citizens: A demoicratic approach’, (2018) 25 Journal of European Public Policy 14031421.

$41 \quad$ Bellamy and Lacey, above n40.

42 A tweet by former special advisor to Prime Minister Theresa May, Nick Timothy published on Twitter, 2 March 2018 (on file with author as screenshot).

$43 \quad$ J Ker-Lindsay, ‘Turkey’s EU accession as a factor in the 2016 Brexit referendum', (2018) 19 Turkish Studies 1-22. 
other. This has evident implications not just for the Brexit calculus by voters, but also for the waning possibilities of EU accession for countries seen as potential sources of such problematic 'free movement' if they are brought into the circle (and not just by the UK). The risks to welfare states are part of the panoply of arguments used - sometimes implicitly rather than explicitly - to deny speedy enlargement in South East Europe. ${ }^{44}$

In sum, what has emerged from the EU's engagement with citizenship across many years is a situation in which the concept itself has been internally and externally contested, and where it is clearly ripe for manipulation by those who seek to find justifications both for maintaining and - as appropriate - disturbing the status quo. To proceed further in the argument, we need a suitable analytical frame for understanding the dynamic effects on citizenship regimes of moves into and out of membership of the EU.

\section{Framing the citizenship consequences of seeking and shunning membership}

Both the EU level citizenship regime and those at the national level (and indeed the connections between the 'levels') are influenced by the decisions that states take when they seek or shun membership of the European Union. These states navigate, not always with a high degree of assurance, a continuum of integration and dis-integration involving dynamics of Europeanisation, de-Europeanisation and sometimes even reEuropeanisation. They engage with other Member States and non-Member States, and with the EU institutions, in complex and often open-ended negotiations which reflect both their own policy preferences and the normative framework of EU law. These states and institutions take decisions which have consequences for the citizenship regimes of the departing or arriving Member States as well as for the EU (and its other Member States) as a whole.

We can understand this best if we combine the analytical frames offered by both citizenship studies and European Union studies. By this means, we can show how Europeanisation and its various counterparts have ebbed and flowed, and how citizenship regimes themselves have evolved as a consequence (and how individuals and groups have reacted to this). To put it another way, Union citizenship is a product not only of a hesitant and fractured process of polity-building beyond the state but also of a move away from a predominantly state-centred conception of citizenship, if not (yet) the death of national citizenship. Union citizenship is normatively dependent upon national citizenship, and European integration creates intense bilateral and multilateral relationships between the national citizenship regimes of the Member States. Various forms of dual and multiple membership come into play, horizontally across the Member States, vertically between the Member States (and their subnational units) and the EU, and across the external borders of the EU, with third countries. These are examples of what Rainer Bauböck calls 'citizenship constellations'. ${ }^{45}$ That is, they are 'structure(s)

The idea of EU citizens (or future EU citizens) as welfare or 'poverty' migrants is reflected in the CJEU's judgment in Case C-333/14 Dano ECLI:EU:C:2014:2358, although the reality is that the migration picture into, across and out of the Western Balkans is rather mixed: International Organisation for Migration Report, Labour Migration Patterns, Policies and Migration Propensity in the Western Balkans, 2010 available at <https://publications.iom.int/books/labourmigration-patterns-policies-and-migration-propensity-western-balkans $>$.

45 R Bauböck, 'Studying Citizenship Constellations', (2010) 36 Journal of Ethnic and Migration Studies $847-859$ at 848 
in which individuals are simultaneously linked to several political entities, so that their legal rights and duties are determined not only by one political authority, but by several.' These constellations contribute to reshaping our ideas about 'what is citizenship?'.

Applying insights from citizenship studies, such as the concept of citizenship constellations, in combination with insights from regional integration studies, such as concepts of de/Europeanisation, will help us to figure out where the boundaries and fractures within this contested concept of membership might lie. More broadly, as case studies, the citizenship dynamics of Brexit and stalled enlargement show that the story of the EU is not one of linear progress of integration towards 'an ever closer union', even though it is still quite common for Union citizenship to be lauded as somehow embodying this historic mission, in accordance with an ineluctable teleology of integration. ${ }^{46}$ Claims continue to be made about narratives of constitutionalism and, especially, constitutionalisation beyond the state, embodying the idea of a single shared citizenship as 'Europe's destiny'. ${ }^{47}$ The better view, however, is to recognise that there is no unidirectional process of Europeanisation in which the elements and constraints generated by Union citizenship are simply downloaded onto national citizenship regimes, with alterations to policies and institutions made accordingly. ${ }^{48}$ On the contrary, there are many (often ambivalent) narratives of Europeanisation and deEuropeanisation simultaneously in play, ${ }^{49}$ as a result of which both national citizenship regimes as well as Union citizenship are likely to be transformed, as the two case studies will illustrate.

Europeanisation is more than just the principle that membership of the EU requires states to comply with EU law and implement legislative measures and new administrative requirements introduced by the EU legislature (in which they participate).$^{50}$ It is also a two-way track in which elements of national choice and institutional 'style' find their way into EU-wide measures and approaches to policymaking as well as into its institutional forms, through national participation in those processes and institutions and also via various types of legal 'borrowing' ${ }^{51}$ From a legal perspective, it incorporates aspects of legal culture as well as formal compliance with EU law. In the enlargement context, Senka Neuman Stanivuković notes that 'EU accession formulates new spaces of political action and creates novel forms of social organisation', including in relation to 'citizenship'. ${ }^{52}$ This is a broad and rather

D Kostakopoulou, 'Scala Civium: Citizenship templates post-Brexit and the European Union's duty to protect EU citizens’ (2018) 56 Journal of Common Market Studies 854-869.

$47 \quad$ See Grzelczyk above n18.

48 D Thym, 'The Evolution of Citizens' Rights in Light of the European Union's Constitutional Development', in Thym above n19. S Worschech, 'The "making” of Europe in the peripheries: Europeanization through conflicts and ambivalences', Culture, Practice \& Europeanization, 2018, Vol. 3, No. 3, 56-76. T Börzel, 'Pace setting, Foot dragging, and Fence sitting: Member State Responses to Europeanisation', (2002) 40 Journal of Common Market Studies 193-214. For a practical example of the application of the insights of Europeanisation to the case of free movement (in the United Kingdom) see J Shaw, 'Between Law and Political Truth? Member State Preferences, EU Free Movement Rules and National Immigration Law’, (2015) 17 Cambridge Yearbook of European Legal Studies 247-286; see also A D’Angelo and E Kofman, 'From Mobile Workers to Fellow Citizens and Back Again? The Future Status of EU Citizens in the UK', (2018) 17 Social Policy and Society 331-343. S Neuman Stanivuković, 'Europeanisation of citizenship in the context of EU accession', in J van der Harst et al above nError! Bookmark not defined. 157-185, at 157. 
sociological concept of Europeanisation which also encompasses societal change as well as 'the convergence of political cultures, the public sphere and collective identities'. ${ }^{53}$ In sum,

Like modernisation or globalisation, Europeanisation also refers to large-scale processes of transformation of contemporary politics and society that are experienced by large groups of people and collectively interpreted. It affects not only economics and politics but also society, which is involved in its interpretation. ${ }^{54}$

A similar approach is useful when analysing de-Europeanisation, which has received less attention than Europeanisation. De-Europeanisation has both formal and ideational elements and involves iterative interchange between the national and EU levels. At the supranational level, it is true that intergovernmental approaches to law and policymaking are once again becoming more common, with a resurgence of control by the member states vis-à-vis the Commission and the CJEU. ${ }^{55}$ At the level of Member States, de-Europeanisation encompasses not just deviations in compliance, but also the alienation of (some) states from the core requirements or principles of integration, through practices such as flexibility and differentiated integration. ${ }^{56}$ It can also incorporate a distinction between 'disengagement' from the EU process and active 'dismantling' of policies and institutions introduced for the purposes of compliance with EU law. ${ }^{57}$ At the boundaries of the EU, it can comprise the denial of accession to states and citizens, so that momentum towards national adjustment to European norms is stalled as the prospect of enlargement recedes into the distance. ${ }^{58}$ De-Europeanisation also encompasses the hitherto unknown phenomenon of exit or withdrawal from the Union, where a Member State negotiates its exit from the EU, but also, for the future, a revised relationship with the EU and its Member States as a third country (which may also involve some elements of re-Europeanisation). Within the withdrawing state, as Burns et al have pointed out, the terms of withdrawal (and the relatively strong embeddedness of EU origin policies and institutions at the domestic level) may lead to more disengagement (and neglect) than actual dismantling. This will vary between different policy areas. Withdrawal of a Member State may lead to relatively little change within the EU itself, although some scholars have now started to explore the broader phenomenon of disintegration. ${ }^{59}$

53 HJ Trenz, The Saga of Europeanisation On the Narrative Construction of a European Society, ARENA Working Paper 7/2014.

$54 \quad$ Trenz, above n53 at 2.

55 CJ Bickerton, D Hodson and U Puetter, 'The New Intergovernmentalism: European Integration in the Post-Maastricht Era', (2015) 53 Journal of Common Market Studies 703-722.

56 R Adler Niessen, Opting Out of the European Union: Diplomacy, Sovereignty and European Integration (Cambridge University Press, Cambridge, 2014).

57 C Burns et al, 'De-Europeanising or disengaging? EU environmental policy and Brexit', (2019) 28 Environmental Politics 271-292 at 273.

58 See the case of Turkey: S Aydın-Düzgit and A Kaliber, 'Encounters with Europe in an Era of Domestic and International Turmoil: Is Turkey a De-Europeanising Candidate Country?’, (2016) 21 South European Society and Politics 1-14.

59 Thus far there has been relatively little scholarly attention focused on disintegration and deEuropeanisation. See W Outhwaite, 'De-Europeanisation after Brexit: narrowing and shallowing’, (2019) 9 Global Discourse 15-30; H Vollaard, ‘Explaining European disintegration', (2014) 52 Journal of Common Market Studies 1142-1159; B Rosamond, 'Brexit and the problem of European disintegration’, (2016) 12 Journal of Contemporary European Research 864-871. 
Just like Europeanisation, citizenship is a complex phenomenon. It cannot simply be understood as a static, top-down, imposed legal framework, in which individuals are given and denied rights or conferred statuses without exercising agency. It is a dynamic and relational concept, rather than a fixed structure, combining plural and multi-level institutional elements as well as the bottom-up practices of citizens as legal and political actors in a non-state context. These practices and resources have been struggled over and contested throughout history and they continue to have both legal and symbolic resonances and effects. ${ }^{60}$ Citizenship might posit an ideal of equality, but real life involves a heterogeneity of citizenship 'experiences', with vectors of gender, class, race and other factors such as ideas about 'security' always conditioning the practical enjoyment of rights or the capacity effectively to perform attendant 'duties'. Citizenship rights have not been even remotely 'equally' allocated at least until well into the twentieth century in most if not all countries. As Claudia Wiesner et al state, 'citizenship in all its dimensions is never neutral, but positioned. ${ }^{\prime} 1$ Another way of characterizing citizenship in these terms is to describe it as 'uneven'. ${ }^{62}$

The idea of a variety of 'citizenship experiences' is as relevant in the context of Union citizenship as it is at the national level. It can be illustrated by reference to the differentiated set of protections and privileges embedded deep within Union citizenship, with many groups not enjoying 'full' citizenship, as predicated on the market freedoms which remain at the core of the concept. This apes the market and political inequalities that lie at the heart of national citizenship. What emerges is a picture of citizenship in the composite and complex euro-polity as a differentiated, rather than a uniform status. In that sense, it reveals similarities to national citizenship. Both offer a promise of equality, but a reality of differentiation.

For example, not all free movers are 'workers' or 'self-employed persons' enjoying the maximum benefits of EU law. Some are students or retired persons who have to prove their self-sufficiency or satisfy other conditions, or dependent members of citizen families who do not accrue rights such as permanent residence easily under the current rules, even in spite of very long residence. What is more, variations in relation to the protective cloak of Union citizenship will also be translated into key vectors of vulnerability and discrimination across lines of disability, gender, sexuality, race, religious and ethnic minority, class, age, documented status, as well as language usage. Women are more likely to be carers, and carers are not easily recognised in the EU legal order. ${ }^{63}$ Ethnic minorities such as the Roma are less likely to be effectively integrated into labour markets. ${ }^{64}$ Children experience their Union citizenship as dependents in different ways to adults. ${ }^{65}$ In practice, therefore, many mobile EU citizens struggle to gain the residence statuses which are essential to enjoying full and effective protection

$60 \quad$ Wiesner et al above n20 at 1.

$61 \quad$ Wiesner et al above n20 at 10

62 G Krasniqi and D Stjepanović, 'Uneven Citizenship: Minorities and Migrants in the PostYugoslav Space’, (2015) 14 Ethnopolitics 113-120.

63 E Caracciolo di Torella, 'The Unintended Consequences of Brexit: the Case of Work-Life Balance', in M. Dustin et al. (eds.), Gender and Queer Perspectives on Brexit (Palgrave, Cham, 2019), 61-91. J Sardelić, 'The position and agency of the 'irregularized': Romani migrants as European semicitizens’, (2017) 37 Politics 332-346.

65 H Stalford, Children and the European Union: Rights, Welfare and Accountability (Hart, Oxford, 2012). 
of the equal treatment principle within the welfare states of most of the Member States. ${ }^{66}$ Those whose lives are marginal to the underlying economic purposes of free movement are often poorly protected against the risk of deportation or other forms of removal or rejection. For example, while unemployment and even rough sleeping resulting from destitution is not as such a reason for removal under EU law, in practice members of these groups are much more vulnerable than others. ${ }^{67}$

Each case of legal marginality stems from the conditions imposed on free movement rights within EU law but it also relies upon an elision in domestic political debate and public opinion, not to mention in public policy and executive action, of any real distinction between 'immigration' more generally and 'free movement' as a special case. ${ }^{68}$ The legal statuses may be differentiated, but in the public perception the activities are often not. Many recent developments in EU free movement policy, including changes introduced in CJEU case law, have in fact flowed from national debates on issues such as welfare benefits for EU citizens and the impact of 'posted workers' operating within the sphere of the free movement of services which have elided free movement and immigration. ${ }^{69}$ Union citizenship is, in sum, rather like a protective - but limited - cloak for certain national citizens.

Beyond the arena of free movement, there are some other areas where the EU has shaped and constrained Member State sovereignty in relation to nationality law. ${ }^{70}$ Through cases such as Micheletti, ${ }^{71}$ Ruiz Zambrano ${ }^{72}$ and Rottmann, ${ }^{73}$ the Court of Justice has developed a doctrine which recognises that Member States must have due regard to the implications of EU law when making decisions about nationality or residence rights which may have the effect of depriving individuals of the enjoyment of their Union citizenship rights. These cases have involved the putative loss of the benefits of Union citizenship through the loss or non-recognition of national citizenship or rights. One question that remains unanswered is the extent to which these same principles could apply to the acquisition of national citizenship.

In 2019, the European Commission issued a report on Investor Citizenship and Residence Schemes in the European Union, exploring how these arrangements for granting citizenship as the counterparty for a financial contribution to the state had proliferated within the EU, how they might fit with Union citizenship law, and what impact they might also have in other areas of EU law such as the fight against

C Bruzelius, 'Freedom of movement, social rights and residence-based conditionality in the European Union' (2019) 19 Journal of European Social Policy 70-83; M Tervonen and A Enache, 'Coping with everyday bordering: Roma migrants and gatekeepers in Helsinki', (2017) 40 Ethnic and Racial Studies 1114-1131. C O’Brien, 'Civis capitalist sum: Class as the new guiding principle of EU free movement rights’, (2016) 53 Common Market Law Review 937-977.

Shaw above $n 51$.

C Barnard and S Butlin, 'Free movement vs Fair Movement: Brexit and Managed Migration', (2018) 55 Common Market Law Review 203-226; N Mussche et al, 'How posting shapes a hybrid single European labour market’, (2018) 24 European Journal of Industrial Relations 113-127.

See Shaw, Still a Fundamental Status?, above n38; H Oosterom-Staples, 'The Triangular Relationship Between Nationality, EU Citizenship and Migration in EU Law: A Tale of Competing Competences', (2018) 65 Netherlands International Law Review 431-461. Case C-369/90 ECLI:EU:C:1992:295. 
corruption, organized crime and indeed tax evasion. ${ }^{74}$ While the Commission's attempt to influence the laws of Member States in the area of citizenship acquisition on the basis of a putative principle of 'genuine links, ${ }^{75}$ as the basis for the citizenship relationship may be relatively weak in doctrinal terms, ${ }^{76}$ none the less the Commission remains within its rights to remind the Member States that one of the main reasons why those who have the requisite resources might wish to purchase one of the national citizenships which are on sale is because it brings with it also the added benefits of Union citizenship. It can be argued that this brings certain responsibilities. That is, under the treaties as they stand, Member States are bound by a duty of loyalty that requires them to 'refrain from any measure which could jeopardise the attainment of the Union's objectives'. ${ }^{77}$ This is one of the cornerstones of the idea of a progressive integration or 'ever closer Union' amongst the peoples of Europe. This reminder about the network of reciprocal duties in respect of citizenship regimes in which the Member States stand albeit it has not been proven exactly what the nature of those legal duties might be provides an important backdrop for reassessing the 'value' of citizenship in the context of the two cases of 'shunning' and 'seeking' membership of the EU to which I shall now turn.

We can now examine the case studies in the light of the conclusion, which has emerged from the juxtaposition of citizenship studies and regional integration studies in this section. We have a 'Europe of many citizenships' (and of many non-citizenships and semi-citizenships), marked by a great deal of market-driven heterogeneity as well limited elements of unity. The narratives in the following sections focus on the political background to processes of Europeanisation, de-Europeanisation and reEuropeanisation, on important legal changes, and on how the climate of uncertainty and/or frustration with these changes (or the lack of them) leads individuals to pursue other options, such as seeking another passport, or deciding to move to another country. The narratives will show that in the context of the multilevel architecture of citizenship in Europe, with the ebb and flow of Europeanisation and integration/dis-integration processes, the two cases of shunned and stalled membership involving contestations at the peripheries of the EU provide good illustrations of a differentiated and often hierarchical concept of Union citizenship, which excludes as much as it includes.

\section{Brexit and the de-Europeanisation of (UK) citizenship}

At first sight, Brexit seems to involve a straightforward process of de-Europeanisation and re-nationalisation (i.e., withdrawal of the UK from the EU and reassertion of UK

$74 \quad$ European Commission, Investor Citizenship and Residence Schemes in the European Union, $\operatorname{COM}(2019)$ 12, 23 January 2019; for a brief review, see Džankić, What's in the EC's report on investor citizenship?, GlobalCIT Blog, 23 January 2019, available at <http://globalcit.eu/whatsin-the-ecs-report-on-investor-citizenship/>.

$75 \quad$ Liechtenstein v. Guatemala (Nottebohm) [1955] ICJ 1.

$76 \quad$ R Thwaites, 'The Life and Times of the Genuine Link', (2018) 49 Victoria University of Wellington Law Review 645-670; A Macklin, 'Is it Time to Retire Nottebohm?' (2017) 111 American Journal of International Law Unbound 492-497. Looked at purely from the perspective of citizenship competences, the Commission's position looks rather weak (J Shaw, 'Citizenship for Sale: Could and Should the EU Intervene?' in R Bauböck (ed) Debating Transformations of National Citizenship, IMISCOE Research Series (Springer International, Cham, 2018) but that is before we factor in questions related to its competences on issues such as money laundering and financial crime.

77 Article 4(3) third sentence TEU. 
sovereignty). It offers, in principle, the opportunity for the UK to favour its own citizens over all other groups (e.g. in the labour market or in relation to public goods) and to reenact symbols of national sovereignty such as dark blue passports.

Given the length of the UK's membership of the EU and the complex intertwining of the UK's citizenship regime and those of the other Member States and of the EU itself, the citizenship consequences of Brexit are set to be legion. Brexit itself is unlikely to be a clean break, when, or if, the UK ever leaves the EU, but also involves probable elements of re-Europeanisation. Assuming the Withdrawal Agreement agreed at the political level in November $2018^{78}$ (along with the accompanying Political Declaration on the UK's future relationship with the $\mathrm{EU}^{79}$ ) is eventually signed, ratified and brought into force, there will be a transition period that could last until the end of 2020 or longer. During this time, free movement (in both directions) would continue although UK citizens would no longer be Union citizens. However, it is unlikely that any final status agreement between the EU and the now third country UK will be ready for many years, raising the question of whether transition will be extended, perhaps indefinitely, or whether there will be a further 'cliff edge' threat each time the end of transition comes close. It is still unclear what any future status agreement might say in relation to the issue of immigration, ${ }^{80}$ unless the UK opts for an arrangement akin to that of the EEA countries (e.g. Norway ${ }^{81}$ ), which includes free movement (but not Union citizenship) as an element of the single market, or Switzerland, which has a dense and complex network of bilateral agreements with the EU including on free movement of persons. ${ }^{82}$ The Political Declaration, as it stands, although vague, presages the end of free movement and points towards a future free trade agreement in the nature of that between the EU and Canada, which says nothing about immigration. ${ }^{83}$

Brexit, in sum, is more process than endstate, and it is hard to predict where it might go in the future. The current leitmotiv is uncertainty and lives 'in limbo', not just because Brexit is an unprecedented situation, but also because the politics of Brexit have become particularly fraught. With UK parliamentary processes for agreeing the

78 For the formalities to allow for signature of the Withdrawal Agreement, see Council Decision 2019/274, ECLI:http://data.europa.eu/eli/dec/2019/274/oj. The text of the Withdrawal Agreement as at 25 November 2018 is published in OJ 2019 C66 I/1. For discussion of the citizens' rights aspects seek O Garner, 'Citizens' Rights in the UK-EU Withdrawal Agreement: Ossifying EU citizenship as a juridical status?’, GlobalCIT Blog, 28 November 2018, available at <http://globalcit.eu/citizens-rights-in-the-uk-eu-withdrawal-agreement-ossifying-eucitizenship-as-a-juridical-status/ $>$. Political Declaration setting out the framework for the future relationship between the European Union and the United Kingdom, 22 November 2018, OJ 2019 C66 I/185.

80 In her Mansion House speech in March 2018, Prime Minister May seemed to suggest there might be a special status in the UK for EU immigration after Brexit but this has yet to be translated into concrete policy. Available at <https://www.bloomberg.com/news/articles/201803-02/prime-minister-theresa-may-lays-out-her-brexit-vision-text $>$. JE Fossum and HP Graver, Squaring the Circle on Brexit: Could the Norway Model Work? (Bristol University Press, Bristol, 2018). Details of the Swiss/EU arrangements on the Swiss Confederal Government website are available at <https://www.sem.admin.ch/sem/en/home/themen/fza_schweiz-eu-efta.html>. A strict separation has been maintained between the Withdrawal Agreement and the future arrangements for immigration between the EU and the UK, reinforced by the deletion of an earlier Article 32 from the draft Withdrawal Agreement, concerning immigration matters, as it belonged only in the future relationship agreement. For discussion see N Nic Shuibhne, 'Brexit Roundup: Free Movement and the Limits of EU Citizenship’, Scottish Centre on European Relations Blog, 18 April 2018, available at: <https://www.scer.scot/database/ident-5635>. 
Withdrawal Agreement stalled at the end of 2018 and throughout the first half of 2019, all the relevant parties (i.e. the UK, ${ }^{84}$ the EU itself, ${ }^{85}$ and the other Member States) were forced to put in place draft or conditional legislation to apply in the case of a 'no deal' Brexit. Such an eventuality could immediately transform the status of already resident EU27 citizens in the UK, or UK citizens in the EU27, into the same as that of other third country nationals. They might struggle to show any lawful excuse to be present on the territory, to be in employment or to be in receipt of welfare benefits. These conservatory measures differ across the countries. ${ }^{86}$ While de-Europeanisation in the event of no deal will occur quite sharply (and painfully) across many policy areas, its effects will perhaps be sharpest of all in relation to matters of free movement, with the UK Government having rapidly put in place the necessary draft legal infrastructure to ensure that all 'new arrivals' after a no deal Brexit would be dealt with under the default rules of UK immigration law. ${ }^{87}$ There is no doubt that the highly centralised nature of UK immigration law makes it possible for the government to institute such a rapid change of course. ${ }^{88}$

One of the mantras of the successful leave campaign became that the UK should 'take back control', specifically of 'our laws, our borders, and our money'. The UK government, led by Prime Minister Theresa May since shortly after the referendum, interpreted this as mandating the termination of free movement. This is a political choice and a 'red' line which limits the options for the UK's future status. If free movement does end, it does so not only for EU27 citizens in the UK, but also for UK citizens in the EU27. This point is often neglected in UK discussions; the dominant rhetoric has been that free movement towards the UK is the challenge to be dealt with, even though economic evidence points in the direction of it having benefited the UK. ${ }^{89}$ The reciprocity of free movement receives little attention and British 'expats', as they are always termed in the media, have found it hard to gain traction for their claims that they too stand to lose a number of valuable benefits, such as options for future onward

See Immigration and Social Security Co-ordination (EU Withdrawal) Bill, for details of passage through Parliament see < https://www.parliament.uk/business/news/2019/parliamentary-news2019/immigration-and-social-security-co-ordination-eu-withdrawal-bill-commons-stages/>. For further information see for details Commons Library Insight, The Immigration Bill: An end to free movement, 15 January 2019, available at <https://commonslibrary.parliament.uk/homeaffairs/immigration/the-immigration-bill-an-end-to-free-movement/>. However, as of 30 April 2019, the UK Government had not published the EU (Withdrawal Agreement) Bill, needed both to enable Brexit to occur and to make good on promises to protect the rights of EU citizens, available at <https://www.gov.uk/government/news/government-confirms-detail-on-new-billthat-will-put-withdrawal-agreement-into-law $>$. A regularly updated overview is available at $<$ https://ec.europa.eu/info/brexit/brexitpreparedness_en>. A regularly updated summary of the measures taken by Member States to protect citizens' rights in the event of a no deal is available at $<$ https://ec.europa.eu/info/brexit/brexitpreparedness/residence-rights-uk-nationals-eu-member-states_en>. CJ McKinney, 'Sweeping new immigration regulations herald the end of free movement', Free Movement Blog, 13 February 2019, available at <https://www.freemovement.org.uk/sweepingnew-immigration-regulations-herald-the-end-of-free-movement/>. For an analysis of the general situation before the publication of the UK's recent materials, but after positions papers by both the UK and the European Commission, see S Peers, 'Staring into the abyss: Citizens' Rights after a No Deal Brexit, EU Law Analysis Blog, 6 December 2018, available at: <eulawanalysis.blogspot.com/2018/12/staring-into-abyss-citizens-rights.html>. Cf. Burns et al above n57 on the ease of dismantling centralised policy areas with few dispersed stakeholders. 
mobility. ${ }^{90}$ Furthermore, when possible future mobility restrictions for UK citizens are raised, these are criticised as being examples of the EU 'punishing' the UK. ${ }^{91}$ On the contrary, it is perfectly reasonable that UK citizens - as third country nationals - would be subject to the European Travel Information and Authorisation System (ETIAS) which was agreed in 2018 by the EU legislature for application within the Schengen zone and which will be in operation from $2021 .{ }^{92}$ Like the US 'ESTA', it is not a visa (UK citizens will be able to travel visa-free to the $\mathrm{EU}^{93}$ ) but an advance travel authorisation system subject to a modest fee (in return for an ETIAS valid for several years) and a criminal records check. It is equally unsurprising that UK citizens resident in Schengen area for more than three months must obtain a visa, although this will in many cases be a matter for national law. This is unlikely to affect those already resident, assuming there is either a Withdrawal Agreement or comprehensive unilateral coverage in the event of no deal, but is likely to affect future student mobility, as well as the travels of holiday-home owners and those seeking to make longer trips whether for work, leisure or to provide services. ${ }^{94}$

The process of de-Europeanisation has already given rise to many difficulties and anxieties. ${ }^{95}$ All international negotiations necessarily involve the principle that 'nothing is agreed until everything is agreed', so that mobile EU citizens on either side of the equation (in the UK or the EU27) have made ideal bargaining chips. Pleas to offer unilateral guarantees to mobile EU citizens - even if heeded - would have inevitably left some groups out and would simply shift the focus of uncertainty and vulnerability to different places. ${ }^{96}$ Latterly, as the risk of no deal has risen, there have been calls, including an amendment adopted by Parliament, to deal with citizens' rights separately to the rest of the Withdrawal Agreement, though this suggestion has not been positively received by the European Commission. ${ }^{97}$ Given the complexities of lives, it is impossible for any Withdrawal Agreement to cover all eventualities, ${ }^{98}$ and it is already visible from the early roll out of the arrangements to gain so-called Settled Status,

For further information see the findings of the research project Brexit Brits Abroad $<$ https://brexitbritsabroad.com/>.

For an analysis, see J Lis, 'No, we're not being bullied by the EU over Brexit', Prospect Magazine, 2 November 2018, available at: <https://www.prospectmagazine.co.uk/politics/themyth-of-brexit-as-punishment>.

Regulation (EU) 2018/1240 ECLI:http://data.europa.eu/eli/reg/2018/1240/oj and Regulation (EU) 2018/1241, ECLI:http://data.europa.eu/eli/reg/2018/1241/oj. Regulation (EU) 2019/592, ECLI:http://data.europa.eu/eli/reg/2019/592/oj. M Klaassen, 'The status of UK citizens in the EU after Brexit', Leiden Law Blog, 7 February 2019, available at: <https://leidenlawblog.nl/articles/the-status-of-uk-citizens-in-the-eu-afterbrexit>.

S Peers, 'EU27 and UK citizens' acquired rights in the Brexit withdrawal agreement: detailed analysis and annotation' EU Law Analysis, 13 March 2018, available at:

<eulawanalysis.blogspot.co.uk/2018/03/eu27-and-uk-citizens-acquired-rights-in.html>; R Ranta and N Nancheva, 'Unsettled: Brexit and European Union nationals' sense of belonging' (2019) 25 Population, Space and Place, DOI: 10.1002/psp.2199; Guma and Dafydd Jones, above n21. On the options for unilateral protection or ringfencing, see S Smismans, 'Six Brexit scenarios for citizens' rights', The UK in a Changing Europe Blog, 12 October 2018, available here: $<$ https://ukandeu.ac.uk/explainers/six-brexit-scenarios-for-citizens-rights/> For the background see S Smismans, Ring-Fencing Citizens' Rights in the Brexit Negotiations: Legal Framework and Political Dynamics DCU Brexit Institute - Working Paper N.1 - 2019, 28 January 2019.

I. Solanke, 'Who Speaks for the Zambrano Families? Multi-level Abandonment in the UK and EU', in M Dustin above n63 at 151-183. 
intended to cover those already resident in the UK, ${ }^{99}$ that more risks will fall precisely upon the vulnerable and marginal categories of EU citizens identified in the previous section, such as those with caring responsibilities that keep them out of the labour market, those who are older (especially those who arrived before the UK became part of the EU), those who are disabled, or even those who experience periods of unemployment that are deemed to render them a burden on the state. ${ }^{100}$ The other group that is vulnerable are those who have even a minor criminal conviction. ${ }^{101}$ Moreover, the position of children may be complex as they are dependent upon their parents taking the appropriate steps towards settlement, and when they become adults they may find that they lack the necessary documentation, both in terms of residence and citizenship. ${ }^{102}$ It should also be noted that the specific complexities of citizenship in Northern Ireland could give rise to particular difficulties. ${ }^{103}$ As Oliver Garner has argued, the gaps in the Withdrawal Agreement will undoubtedly be litigated in the national courts, and before the CJEU or some other bespoke court, highlighting the complexities of de-Europeanisation ${ }^{104}$ Scholars and activists also fear that there will be an implementation and enforcement gap, if institutions to assist EU citizens in navigating any new systems are not established, ${ }^{105}$ and if the correct approach to EU

99 Details of the UK's Settled Status and Pre-Settled Status for EU and EEA citizens who have been in the UK for five years (or less in the case of pre-settled status):

$<$ https://www.gov.uk/settled-status-eu-citizens-families>. The scheme (and fears that the Home Office will not cope) is discussed in Getting it Right from the Start. Securing the Future for EU Citizens in the UK, A Report for British Future by Jill Rutter and Steve Ballinger, January 2019, available at: <http://www.britishfuture.org/articles/eu-settlement-scheme/>.

$100 \quad$ See M Sumption and Z Kone, Unsettled Status. Which EU citizens are at risk of failing to secure their rights after Brexit?, Migration Observatory Report, COMPAS, University of Oxford, 12 April 2018, available at: <http://migrationobservatory.ox.ac.uk/wp-

content/uploads/2018/04/Report-Unsettled_Status.pdf >; see also S Zawacki, 'Fear Mounts as Roma Prepare to Apply for Post-Brexit Settled Status in the UK', The Conversation, 22 August 2018, available at: <https://theconversation.com/fear-mounts-as-roma-prepare-to-apply-for-postbrexit-settled-status-in-the-uk-100710> and ILPA briefing, EU Settled Status Automated Data Checks, 30 January 2019, available at: <http://www.ilpa.org.uk/resources.php/35100/eu-settledstatus-automated-data-checks-ilpa-research-piece-30-january-2019>.

101 A Bulat, 'The rights of non-UK EU citizens living here are not a "done deal”. This is why', LSE Brexit Blog, 27 February 2018, available at: <https://blogs.lse.ac.uk/brexit/2018/02/27/therights-of-non-uk-eu-citizens-living-here-are-not-a-done-deal-this-is-why/>. In response to legal action brought by the Joint Council for the Welfare of Immigrants, changes were made in that area to the Scheme by the Home Office in March 2019. For details see:

$<$ https://www.freemovement.org.uk/home-office-softens-eu-settled-status-requirements-aftercharitys-legal-action/>.

102 C Yeo, 'The impact of the UK-EU agreement on residence rights for EU families', Eurochildren Research Brief, 1, 2018; C Yeo, 'The impact of the UK-EU agreement on citizenship rights for EU families’, Eurochildren Research Brief, 2, 2018.

103 B Warwick, 'A Windrush in waiting: post-Brexit categories of citizen in Northern Ireland', LSE Brexit Blog, 11 September 2018, available at: <https://blogs.lse.ac.uk/brexit/2018/09/11/awindrush-in-waiting-post-brexit-categories-of-citizen-in-northern-ireland/>.

104 O Garner, 'Citizens’ Rights in the UK-EU Withdrawal Agreement: Ossifying EU citizenship as a juridical status?', GlobalCIT Blog, 28 November 2018, available at: $<$ http://globalcit.eu/citizens-rights-in-the-uk-eu-withdrawal-agreement-ossifying-eu-citizenshipas-a-juridical-status/>.

105 S Smismans, 'EU citizens in the UK are in a particularly weak position and need an independent authority to monitor their rights’, LSE Brexit Blog, 26 March 2018, available at: <https://blogs.lse.ac.uk/brexit/2018/03/26/eu-citizens-in-the-uk-need-a-independent-authorityto-monitor-their-rights/>. 
law in the UK is not taken. ${ }^{106}$ Finally, it should be noted that once again rather more attention has been paid to the situation of EU27 citizens resident in the UK than to that of UK citizens resident in the EU27. ${ }^{107}$

Prospects for the loss of Union citizenship (and the associated rights which this gives) have provoked unprecedented levels of mobilisation, ${ }^{108}$ including calls to save Union citizenship for some or all UK citizens, perhaps through a form of 'associate citizenship'. ${ }^{109}$ This plea seems utopian as well as impractical in a legal sense. ${ }^{110}$ NGOs have mobilised to scrutinise the negotiating process and press for the best outcome possible in the event of withdrawal for UK and EU27 citizens, a challenging task in the face of a constantly changing landscape of proposals and counter-proposals. ${ }^{111}$ Work has been undertaken to document the 'in limbo' experienced by those directly affected. ${ }^{112}$ Some individuals have chosen to turn their back on free movement by returning to their state of citizenship or choosing not to move, to avoid facing Brexit uncertainties, ${ }^{113}$ while others are sitting tight waiting to see what strategy the UK and the EU/other Member States pursue. For another group, the preferred strategy has been to collapse their acts of Union citizenship back into acts of national citizenship, by obtaining citizenship of the host state (naturalisation), by seeking or re-activating a second 'backstop' citizenship (e.g., by ancestry or family ties), ${ }^{114}$ or by making use of a default second citizenship (as in the case of UK citizens born in Northern Ireland who can choose to be Irish or British or both under the Good Friday Agreement). ${ }^{115}$ For

106 See S Smismans, 'EU citizens' rights post Brexit: Why direct effect beyond the EU is not enough', (2018) 14 European Constitutional Law Review 443-474 and P Daly et al, Brexit and EU Nationals: Options for Implementation in UK Law, University of Cambridge Faculty of Law Research Paper No. 1/2018. Available at <https://ssrn.com/abstract=3077036>.

$107 \quad$ For a counter balance, see Klaassen above n94.

108 V Brändle, C Galpin and HJ Trenz, 'Marching for Europe? Enacting European citizenship as justice during Brexit', (2018) 22 Citizenship Studies 810-828.

109 See European Citizens' Initiative on Permanent European Citizenship registered by the Commission, Press Release IP/18/4566, 18 July 2018, available at:

$<$ http://europa.eu/rapid/press-release_IP-18-4566_en.htm>. A Yong, 'Britons shouldn't get their hopes up about keeping EU citizenship after Brexit', The Conversation, 21 February 2018, available at: <https://theconversation.com/britons-shouldntget-their-hopes-up-about-keeping-eu-citizenship-after-brexit-91501>; also negative is AP van der Mei, 'EU Citizenship and Loss of Member State Nationality', (2018) 3 European Papers 1319-1331. Compare the argument of O Garner, 'The Existential Crisis of Citizenship of the European Union: The Argument for an Autonomous Status', (2018) 20 Cambridge Yearbook of European Legal Studies 116-146.

111 K Jablonowski, 'You Don't Have Rights, You Use Them: Brexit and European Citizenship', Sociological Review Blog, 13 July 2017 available at:

<https://www.thesociologicalreview.com/blog/you-dont-have-rights-you-use-them-brexit-andeuropean-citizenship.html>.

112 Examples of the advocacy work involving the highlighting of personal narratives are available at: <http://www.ourbrexitblog.eu/blog/category/in-limbo/>.

113 'Net Migration from EU to UK falls 70\% since Brexit vote', Financial Times, 28 February 2019, available at: <https://www.ft.com/content/960b4672-3b3e-11e9-b72b-2c7f526ca5d0>; migration statistics for the UK are available at:

$<$ https://www.ons.gov.uk/peoplepopulationandcommunity/populationandmigration/international migration $>$.

114 On the common case of Irish ancestry for UK citizens, see P Burke Wood and M Gilmartin, 'Irish enough: changing narratives of citizenship and national identity in the context of Brexit', (2018) 22 Space and Polity 224-237.

115 The Belfast Agreement, 10 April 1998, available at: $<$ https://www.gov.uk/government/publications/the-belfast-agreement>; see 'UK accused of not honouring dual citizenship commitments’, The Irish Times, 6 March 2019 available at: 
those wealthy enough, there exists the option of purchasing citizenships and residencies in a number of Member States with minimal physical residence obligations. ${ }^{116}$ Many of these strategies - involving what Yossi Harpaz calls 'compensatory citizenships' - call for a closer look at the ever more complex relationship between Union citizenship and national citizenship, already hinted at in the previous section. ${ }^{117}$

Union citizenship is a creature of EU law, but it is based on access points controlled under national law. The McCarthy case suggested that those with dual citizenship of the host state and another Member State do not enjoy the protection of EU law as regards the right to reside because the situation is one that is purely internal to the host state. ${ }^{118}$ More recently, the Lounes case took a different approach in the case of a person who naturalised after having migrated to the host state. ${ }^{119}$ Furthermore, the CJEU has held that EU law requires the possibility of judicial review of decisions on deprivation of national citizenship, if this would have the effect of depriving an EU citizen of substantially all of the benefits of Union citizenship. However, this proposition was developed for a scenario where it was the actions of the EU citizen in question - in combination with national citizenship laws - which triggered the scenario in which he or she was deprived of the benefits of Union citizenship ${ }^{120}$ and has not always been received favourably at the national level. ${ }^{121}$ It is not yet known how the CJEU might approach the question of loss of Union citizenship because a Member State withdraws from the EU. ${ }^{122}$ A lower court referral of such a question to the CJEU in the Netherlands in a case raised before it by aggrieved UK citizens fearing loss of their Union citizenship was subsequently overturned on appeal. ${ }^{123}$ In any event, the prospects for success in such a case are rather limited. ${ }^{124}$

\footnotetext{
<https://www.irishtimes.com/news/world/europe/uk-accused-of-not-honouring-dual-citizenshipcommitments-1.3816393>.

116 Cf Commission Report on Investor Citizenship above n74.

117 Y Harpaz, 'Compensatory citizenship: Dual nationality as a strategy of global upward mobility', (2018) Journal of Ethnic and Migration Studies DOI: 10.1080/1369183X.2018.1440486.

118 Case C-434/09 McCarthy v SSHD ECLI:EU:C:2011:277.

119 Case C-165/16 Lounes v SSHD ECLI:EU:C:2017:862. For commentary see D de Groot, 'Free Movement of Dual EU Citizens', (2018) 3 European Papers. 1075-1113. Case C-135/08 Rottmann v Freistaat Bayern ECLI:EU:C:2010:104. See the judgment of Laws LJ, at para 43, in G1 v Secretary of State for the Home Department, [2012] EWCA Civ 867.

122 For suggestions, see A Schrauwen, '(Not) Losing out from Brexit'. (2017) 1 Europe and the World 1-18; P Mindus, European citizenship after Brexit. Freedom of movement and rights of residence (Palgrave Macmillan, London, 2017); N Cambien, 'Residence Rights for EU Citizens and Their Family Members: Navigating the New Normal’, (2018) 3 European Papers 13331352. The adoption of a human rights approach would require a significant shift on the part of the CJEU, given the limitations of the approach of the European Court of Human Rights to nationality issues: M Dembour, 'Ramadan v. Malta: When will the Strasbourg Court understand that nationality is a core human rights issue?’, Strasbourg Observers, 22 July 2016, available at: $<$ https://strasbourgobservers.com/2016/07/22/ramadan-v-malta-when-will-the-strasbourg-courtunderstand-that-nationality-is-a-core-human-rights-issue/>.

123 'Appeal judges reject British EU citizenship claim, won't refer to EU court', Dutch News, 21 June 2018, available at: <https://www.dutchnews.nl/news/2018/06/appeal-judges-reject-britisheu-citizenship-claim-wont-refer-to-eu-court/>. 
Absent an international agreement specifically preserving the status of Union citizenship or certain rights attaching to it, it seems obvious that a withdrawing state retains the power, under international law, to deprive its citizens of the status of EU citizen, and to render the legal effect of that status, for citizens of other continuing Member States, nugatory within its territory. The Court of Justice in the Wightman case confirmed this scenario implicitly by noting that

since citizenship of the Union is intended to be the fundamental status of nationals of the Member States any withdrawal of a Member State from the European Union is liable to have a considerable impact on the rights of all Union citizens, including, inter alia, their right to free movement, as regards both nationals of the Member State concerned and nationals of other Member States. ${ }^{125}$

In similar terms, other Member States have no obligation to treat UK citizens other than as third country nationals on their territory, subject to the requirements of the Withdrawal Agreement or the normal rules of EU law relating, for example, to long term resident non-EU citizens. ${ }^{126}$ Furthermore, the European Commission has not pushed the issue at all, and has - according to Steve Peers - displayed indifference to the situation to be faced by UK citizens in the event of a no deal Brexit. ${ }^{127}$ In addition, as a type of backstop, there should be protection of non-citizen residents of the withdrawing or remaining states in relation to certain rights, such as family life, under international human rights law (which may not require very long residence). The Kuric case of the European Court of Human Rights ${ }^{128}$ appears to 'freeze' the rights of those who have regular residence in the host state and who do not accede to the citizenship of that state when it 'secedes' (i.e., in the case of the EU, withdraws). ${ }^{129}$ Although developed in the context of the secession of Slovenia from the Socialist Federal Republic of Yugoslavia in 1992, the principles in this case should be applied by analogy to a UK withdrawal from the EU to protect the minimum rights of affected persons in the UK and the EU27. ${ }^{130}$ This residual protection may be the limit of the 'stickiness' of Union citizenship after Brexit.

One possible caveat upon the general principle that national citizenship is unaffected by Brexit was to be anticipated in the Tjebbes case, concerning legislation withdrawing Dutch citizenship from persons who are resident for more than 10 years in a third country and who have taken on that country's citizenship. ${ }^{131}$ Such a case has obvious implications for the post-Brexit scenario, as the UK will be such a 'third country' after Brexit, so any intervention by the CJEU to suggest that Member States are not free to

See Wightman above n1 at para.64. The CJEU made this statement to buttress the argument that the decision to leave the EU must be a voluntary sovereign act, so that it followed that a Member State is in a position to withdraw its Article 50 TEU notification unilaterally, subject to the condition that this notice should be unequivocal and unconditional. S Peers, 'UK citizens as non-EU citizens in the EU after Brexit: applying the EU Directive on non-EU long-term residents’, EU Law Analysis Blog, 27 December 2018, available at: $<$ http://eulawanalysis.blogspot.com/2018/12/uk-citizens-as-non-eu-citizens-in-eu.html>.

$127 \quad$ See Peers above n87.

$128 \quad$ Kuric and Others v Slovenia, No 26828/06, [2013] 56 EHRR 20. 
withdraw citizenship in such circumstances could be for the benefit of those resident in the UK who, unlike UK citizens, face restrictions on holding dual citizenship. In July 2018, Advocate General Mengozzi issued his Opinion concluding that Netherlands law was incompatible with EU law as regards the effects on minors, but not adults. ${ }^{132}$ However, the CJEU declined to follow the Advocate General, finding that the law in this case is compatible with EU law and with citizenship of the Union, provided that each case is reviewed individually and providing authorities - and courts as appropriate - can determine that the loss of nationality that entails the loss of Union citizenship is proportionate, bearing in mind the consequences for the person affected and, if relevant, members of their family. This is line with earlier cases such as Rottmann, and opens the way at least for individuals insist on judicial review of their particular circumstances. This could mean that individuals will seek to have the Netherlands authorities have regard to circumstances outwith their control, if the UK does exit the EU.

We could certainly postulate that adjustments to national citizenship laws might be a desirable part of the solution to the upheaval brought about by Brexit. But the UK is making no moves to facilitate citizenship access for resident non-citizens, despite the loss of their preferential 'free mover' status. On the contrary, it seems that this group must accommodate themselves to the UK's requirements, rather than the other way around, by applying for 'settled status' even though this falls far short of both national citizenship and of the protections and freedoms previously offered by Union citizenship. ${ }^{133}$ Somewhat begrudgingly, though, the UK Government did remove the fee of $£ 65$ attached to this registration requirement in January 2019. ${ }^{134}$ Many EU citizens resident in the UK are pursuing the UK citizenship route despite the considerable expense and the numerous bureaucratic hurdles in place. ${ }^{135}$ For children born in the UK, there may be options to register as UK citizens, depending upon their parents' status at the time of birth and how long they have lived here, although this process is also expensive and difficult. ${ }^{136}$ The irony is that many are seeking UK citizenship not because they feel more integrated in the UK, but precisely because they face more hostility than ever before. A wave of xenophobia has been unleashed by the UK's

\footnotetext{
$132 \quad$ ECLI:EU:C:2018:572.

133 For details see above n99.

134 For details see Home Office in the media, Factsheet: EU Settlement Scheme fee waiver, 21 January 2019, available at: <https://homeofficemedia.blog.gov.uk/2019/01/21/factsheet-eusettlement-scheme-fee-waiver/>.

135 Barriers include (a) obtaining an EU permanent residence card (under existing EU law), which requires a person not working to show that they have private health insurance; (b) passing the life in the UK test; (c) high fees; and (d) passing a good character test. Details are available at: <https://www.gov.uk/apply-citizenship-eea>. In the UK, the share of citizenships granted to other EU citizens increased from 12\% to 24\% between 2016 and 2017: see 'Naturalisation as a British Citizen: Concepts and Trends', 3 August 2018, available at:

<https://migrationobservatory.ox.ac.uk/resources/briefings/naturalisation-as-a-british-citizenconcepts-and-trends/ $>$. The true scale of the Brexit related push towards the acquisition of a new citizenship is yet to emerge, but anecdotal evidence has been gathered, e.g. Stephen Paduano, 'The Great British Race to Get a Second Passport', Foreign Policy, January 29 2019, available at: <https://foreignpolicy.com/2019/01/29/britains-great-race-to-get-a-second-passport/>. Eurostat figures for 2017 (EU Member States granted citizenship to over 800 thousand persons in 2017, Eurostat News release 41/2019, 6 March 2019) highlight that within the EU only Romanians and Poles exceeded the number of UK citizens acquiring another EU citizenship, and the number of UK citizens acquiring another citizenship more than doubled between 2016 and 2017 (6,555 to 14,911). See Yeo Eurochildren Research Brief, 2 above n102.
} 
'Brexit experience', ${ }^{137}$ with consequent mental health impacts. ${ }^{138}$ The UK feels less like home for this group and so the form of security offered by formal citizenship seems more desirable. In one sense, those naturalizing are accepting the veracity of Theresa May's post-Brexit dictum: 'if you believe you're a citizen of the world, you're a citizen of nowhere and you don't know what citizenship is. ${ }^{\text {' }} 39$ They are making themselves citizens of somewhere: the United Kingdom.

Initially, there was no sign of Member States with restrictive approaches to dual citizenship, such as the Netherlands, Lithuania, Estonia or Austria, making adjustments to citizenship law to accommodate resident UK citizens or to protect their own citizens' interests in relation to the loss of Union citizenship status in the UK. On the contrary, the Prime Minister of the Netherlands appeared to double down on his country's resistance to dual citizenship. ${ }^{140}$ However, perhaps in a harbinger of further changes to come, in October 2017 the incoming Dutch coalition adopted a more liberal approach to dual citizenship, offering assurances to Dutch citizens resident in the UK that they would be able to keep their Netherlands citizenship after naturalising in the UK, ${ }^{141}$ although concrete steps have yet to be taken. In its Brexit preparations, Germany proposed to extend the leeway to protect dual citizenship given to EU citizens to those UK and German citizens who have applied for, but not yet received, the citizenship of the other country on the date of the UK withdrawal to benefit from dual citizenship. ${ }^{142}$

There remained still many mixed-nationality families, as well as highly mobile persons, who find that national citizenship acquisition does not match up to the fluid flexible possibilities of Union citizenship and free movement. Engaging with UK governmental authorities has thrown up not just practical, but also symbolic issues. According to Roberto Gonzales and Nando Sigona this is to do with

the distance between a normative construction of the EU citizen as someone who feels at home everywhere in the EU and is valued for embracing freedom of movement within the EU, both long and short term, and that of the immigrant in the UK who may see their chances of 2016-17, HL Paper 82; Guma and Dafydd Jones above n21; Ranta above n95. communities across the UK: the impact on mental health’ (2018) 111 Journal of the Royal Society of Medicine 158-161;

139 The full text of May's speech is available at: $<$ https://www.telegraph.co.uk/news/2016/10/05/theresa-mays-conference-speech-in-full/>. 'Dutch nationals taking UK citizenship 'will lose Netherlands passports', The Guardian, 17 July 2017; available at: <https://www.theguardian.com/politics/2017/jul/17/dutch-nationalsbrexit-uk-citizenship-lose-netherlands-passports-mark-rutte>. See 'Brexit: Dutch nationals living in Britain will be allowed dual citizenship', The Guardian, 10 October 2017, available at: <https://www.theguardian.com/world/2017/oct/10/dutchnationals-living-britain-allowed-dual-citizenship-brexit>; ' D66 calls for relaxation of dual nationality rules for people hit by Brexit’, Dutch News, 28 January 2019 available at: $<$ https://www.dutchnews.nl/news/2019/01/d66-calls-for-relaxation-of-dual-nationality-rules-forpeople-hit-by-brexit/>.

142 See 'Brexit Transition Act', Federal Foreign Office, 1 February 2019 available at: $<$ https://www.auswaertiges-amt.de/en/aussenpolitik/europa/transitional-brexitact/2119778>.
} 
permanent residency jeopardised if they happen to have spent too many days abroad. ${ }^{143}$

These feelings in relation to 'home' 144 will become all the more intense as the UK continues down the track towards leaving the EU, and as the current set of legal arrangements is superseded by others based at least partly on the disciplining force of national immigration law, rather than the enabling principles of freedom of movement or the constitutional notion of the 'citizen of the Union'. These dislocated feelings of being let down by state and international institutions in relation to the opportunities offered by Union citizenship, at least on the part of those for whom the reality of Union citizenship has become a social fact, may bear some similarities to the loss of hope and expectation experienced by citizens of the states of south east Europe, as I shall show in the next section. They are exacerbated by the fact that very few of the most directly affected persons had a right to vote in the referendum, with the exception of Irish and Commonwealth EU (i.e. Maltese and Cypriot) citizens resident in the UK and UK citizens resident outside the UK for fewer than 15 years. ${ }^{145}$

This case study of the de-Europeanisation and re-Europeanisation of citizenship although still shrouded in uncertainty - illustrates the messy unravelling of the UK's membership of the euro-polity. It highlights too that the consequences are not limited to simple binary changes (UK citizens cease to be Union citizens; UK territory ceases to be part of the EU), not least because of the need to protect those whose lives have been constructed on the basis of an assumption of the durability of the protective cloak of Union citizenship and because of the agency of individuals in relation to multiple incidents of citizenship. Consequently, the Brexit process has to be seen not just a negotiation between the UK and the European Commission (acting on behalf of the institutions and the EU27) but also as a range of actions on the part of individuals and groups incentivised to change their legal situation as a consequence of the threats to the status quo posed by the UK's referendum result. ${ }^{146}$ In the next section, we will see to what extent there are parallels to be drawn between these observations and the case of stalled enlargement.

\section{The stalled Europeanisation of citizenship in south east Europe}

The shadow that Union citizenship will cast after the UK leaves the EU (based on the complexity of untangling existing legal obligations) inevitably differs from the shadow cast by Union citizenship on candidate or putative candidate states and their citizenship regimes before accession (or in the case of stalled enlargement, without accession).

Candidate states comply with EU law not because they are subject to a legal obligation under the EU Treaties, but because they are incentivised by what Tanja Börzel calls 'the

\footnotetext{
143 R Gonzales and N Sigona, 'Mapping the soft borders of citizenship: an introduction', in R Gonzales and N Sigona (eds), Within and Beyond Citizenship: Borders, Membership and Belonging (Taylor and Francis, London, 2017) 1-16 at 2.

144 R Miller, '(Un)settling home during the Brexit process' (2019) 25 Population, Space and Place, DOI: $10.1002 / p s p .2203$. See J Shaw, 'Unions and Citizens: Membership Status and Political Rights in Scotland, the UK and the EU', in Closa above n15, 153-186.

146 HUJ d'Oliveira, Brexit, Nationality and Union Citizenship: Bottom Up, EUI Working Paper, RSCAS 2018/49.
} 
shadow of hierarchy' ${ }^{147}$ In the case of accession, this relates to the inequality of bargaining power between an individual candidate state and the EU, its institutions and its Member States, the latter wielding the 'acquis communautaire', compliance with which is a necessary condition for accession. This presents an interesting contrast to the imprint of the acquis in the context of withdrawal from the Union, even though a similar inequality of bargaining power between the withdrawing state and the EU has become visible during the Brexit negotiations. Escaping the acquis is no simple matter and, as we have seen, has both direct and indirect impacts upon citizenship regimes, which together illustrate the complex and 'messy' nature of the EU's multilevel constitutional setup. From the perspective of accession, the acquis comprises not only the body of laws and policies that candidate states must have in place when they accede, but also the broader requirements related to the so-called Copenhagen criteria, in particular compliance with the rule of law, democracy and fundamental rights, as well as progress towards a market economy. ${ }^{148}$ These criteria were solidified after 1989 precisely in order to deal with the challenges of transition in central, eastern and south eastern Europe. It is often in this latter domain, in the absence of specific competences at the EU level affecting most aspects of the acquisition and loss of citizenship, that the effect of complying with the acquis is felt most intensively by candidate states. It is here, given the arrested state-building processes of many of the new states of South East Europe, ${ }^{149}$ not to mention in the manifold problems of corruption in the emerging market places, that reluctant Member States can also find reasons to block or delay enlargement based on a fear that the EU at present has reached the limits of its so-called absorption capacity and 'enlargement fatigue' has set in. ${ }^{150}$

However problematic stalled enlargement may be, it differs from Brexit as it does not involve the reliance or trust dynamic that is so prominent in the case of Brexit both for UK citizens in the EU27 and EU27 citizens in the UK. It is one of the ironies of Brexit that it appears to visit upon UK citizens and upon EU citizens resident in the UK the uncertainties and sense of exclusion that south east Europeans have long confronted in the context of the disintegration of states in the region and the failed promises of a 'European future'. ${ }^{151}$ But equally, there is nothing akin to the threat of a 'no deal Brexit' in the sphere of enlargement. Enlargement negotiations may stall, but they will not result in a sudden and potentially very damaging change of status. On the contrary, stagnation freezes the current status (and also in many respects the relationships between the various candidate states), and it is this which generates the conditions under which there is only limited Europeanisation of the citizenship regimes of the new states of south East Europe and under which a variety of individualised Europeanisation strategies are embarked upon by citizens in the region.

A closer look at these citizenship regimes produces a similarly fragmented picture to that which we have seen in the case of the ongoing saga of Brexit. Changes within and across the citizenship regimes of the new states of South East Europe stem not just from

\footnotetext{
147 See Börzel above n2 and T Börzel and T Risse, 'From Europeanisation to Diffusion: Introduction', (2012) 35 West European Politics 1-19.

148 C Hillion, 'Accession and Withdrawal in the Law of the European Union', in D Chalmers and A Arnull, The Oxford Handbook of European Union Law (Oxford University Press, Oxford, 2015). S Keil, 'Europeanization, State-building and democratization in the Western Balkans', (2013) 41 Nationalities Papers 343-353.

150 J O’Brennan, ““On the Slow Train to Nowhere?” The European Union, "Enlargement Fatigue”and the Western Balkans’, (2014) 19 European Foreign Affairs Review 221-242. Dembour, above n122.
} 
the candidate or putative candidate status of each of these states, but also from the exigencies of domestic politics as well as from a variety of other exogenous factors (including the role of international organisations other than the EU as well as the policies and laws of neighbouring states). ${ }^{152}$

In the former Yugoslavia, the period after 1991 saw a period of re-nationalisation, both in the form of new states being established each with their own citizenship regime, but also in relation to the restrictions imposed on the citizens of those states. Of the European socialist states before 1989, the Socialist Federal Republic of Yugoslavia (SFRY) had the closest relations with the then European Communities. ${ }^{153}$ It had benefitted from its break with the Soviet Union after 1948 to develop a unique decentralised market socialism model based on employee-managed firms which made it a more comfortable partner for the European Communities and the Member States than other socialist countries, albeit that it continued to display significant rule of law, democracy and human rights deficits. Its citizens enjoyed visa free travel across most of Europe, relying on the old red Yugoslav passport, at a point in time when visas remained solely a matter of national competence. ${ }^{154}$ Substantial numbers of guest workers from Yugoslavia lived, worked and settled in western European states including Germany, Austria and Sweden, and through naturalisation became themselves EU citizens after the Treaty of Maastricht came into force (and after the 1995 accession of the latter two states). The large groups of former Yugoslav citizens resident in Switzerland have enjoyed similar networks of economic and mobility rights across the EU under the bilateral arrangements governing Swiss/EU relations, once they (or more likely their children) have acquired Swiss citizenship. Transnational lives became commonplace for former Yugoslav citizens, whether they migrated before or after 1991. ${ }^{155}$ Yet at the same time, especially in the 1980s, SFRY experienced intense challenges of its own particularly related to centre-periphery relations within an increasingly decentralised state. These troubles eventually contributed to the post-1989 democratisation processes within Yugoslavia taking place at the level of the Republics, not at the federal level. By the end of the 1980s it was also facing huge economic problems related to international debt and the failure of its economic model. Centrifugal political forces, which included challenges around issues of citizenship and identity, ${ }^{156}$ along with economic problems, not to mention the absence of a clear single view from the European Communities of twelve Member States all contributed to the eventual, complex, and sometimes violent break up processes.

\footnotetext{
152 J Shaw, 'The constitutional mosaic across the boundaries of the European Union: citizenship regimes in the new states of South Eastern Europe', in N Walker et al (eds), Europe's Constitutional Mosaic (Hart, Oxford, 2011) 137-170; J Shaw and I Štiks, 'Introduction: Citizenship in the new states of South Eastern Europe’, in J Shaw and I Štiks (eds), Citizenship after Yugoslavia (Routledge, London, 2013) 1-13 at 6-10.

153 See n10 above.

$154 \quad$ For more on citizenship in SFRY see I Štiks, Nations and citizens in Yugoslavia and the postYugoslav states: one hundred years of citizenship (Bloomsbury Academic, London, 2015) Chapters 3-5.

155 J Dahinden, 'Understanding (Post-)Yugoslav Migration through the Lenses of Current Concepts in Migration Research: Migrant networks and transnationalism', in U Brunnbauer (ed), Transnational Societies, Trans-territorial Politics. Migration in the (Post-) Yugoslav Area, 19th21st Century (De Gruyter, Berlin/Boston, 2009). Stiks, above n154, Ch 6.
} 
The (national) citizenship governance challenges arising from the break-up of SFRY are many and varied and there is now an extensive literature documenting them. ${ }^{157}$ As the baseline for the majority of states when determining their initial citizenry was the rather neglected status of citizenship at the republican level within Yugoslavia, there inevitably remain many unsettled questions about citizenship, dual citizenship, external citizenship and national minorities within those new states. ${ }^{158} \mathrm{~A}$ dominant characteristic of the early citizenship regimes in the region was to posit the state, constitutionally speaking, as the 'state of the titular majority', rather than the 'state of its citizens'. ${ }^{159}$ Many people, especially ethnic minorities and those who had migrated within the former Yugoslavia, became refugees and displaced persons both within the region and beyond, although some of whom were able to return and reclaim citizenship and residence in the new state. ${ }^{160}$ This is what Igor Štiks has termed 'ethnic engineering' in relation to citizenship. ${ }^{161}$ Even so, Gëzim Krasniqi and Dejan Stjepanović reject the argument that ethnic politics somehow explains all the instances of what they call 'uneven citizenship' across the region. When they use this descriptor, they are able to

not only discuss exclusionary legal, political and social practices but also other unanticipated or unaccounted for results of citizenship policies that were based on specific criteria of membership. Sometimes...the criteria of membership and citizenship policies are conditioned by broader normative conceptions such as multicultural citizenship and differentiated citizenship and might not be ab initio defined as exclusionary, although the application of such criteria might lead to that outcome in practice. ${ }^{162}$

Many examples show that ethnic politics is not the only factor when it comes to understanding outcomes. For example, issues of state authority and recognition (e.g., in Bosnia and Herzegovina and Kosovo) continue to affect the quality of the citizenship status and rights. ${ }^{163}$ Plebiscites were held in circumstances where franchise definitions have been highly politicised (e.g., for Montenegro’s separation from Serbia). ${ }^{164}$ Citizenship coverage is not comprehensive: there remain, for example, substantial numbers of stateless Roma, especially in Montenegro and Macedonia. ${ }^{165}$ There are frozen conflicts with citizenship dimensions within the region, for example between Kosovo and Serbia, or within Bosnia and Herzegovina as regards the secessionist claims

157 See Štiks above n154; Shaw and Štiks above n152; J Džankić, Citizenship in Bosnia and Herzegovina, Macedonia and Montenegro: Effects of statehood and identity challenges (Ashgate, Farnham, 2015).

$158 \quad$ Shaw and Štiks above n152.

159 R Hayden, 'Constitutional Nationalism in the Formerly Yugoslav Republics', (1992) 51 Slavic Review 654-673.

160 B Đorđevic, 'Whose Rights, Whose Return? The Boundary Problem and Unequal Restoration of Citizenship in the Post-Yugoslav Space', (2015) 14 Ethnopolitics 121-139; V Koska, 'Refugee Integration and Citizenship Policies: The Case Study of Croatian Serbs in Vojvodina’, (2017) 14 Ethnopolitics 180-196.

161 I Štiks, 'Nationality and Citizenship in the Former Yugoslavia: From Disintegration to the European Integration’, (2006) 6 South East European and Black Sea Studies 483-500.

$162 \quad$ Krasniqi and Stjepanović above n62 at 114.

163 See Džankić above n157.

164 J Džankić, Country Report. Montenegro, EUDO Citizenship/GlobalCIT, November 2012, at footnote 9 , available at:

$<$ http://cadmus.eui.eu/bitstream/handle/1814/19627/RSCAS_EUDO_CIT_CR_2012_05.pdf >. J Sardelić, 'Romani Minorities and Uneven Citizenship Access in the Post-Yugoslav Space’, (2015) 14 Ethnopolitics 159-179. 
of the Republika Srpska. Bosnian citizenship itself is a complex multilevel network of rights, privileges and duties, determined by the flawed consociationalist Dayton Constitution imposed in order to end the fighting. ${ }^{166}$ This is just one example of major changes to national citizenship regimes introduced as a result of exogenous pressures. ${ }^{167}$ Other examples of direct impacts of external actors on the national citizenship regimes can be seen in the impact of the Ohrid Accords in Macedonia in relation to opening out citizenship acquisition by Macedonia's Albanian minority ${ }^{168}$ and the fact that Kosovo's first citizenship law was written into the Ahtisaari Plan for a Kosovo status settlement. ${ }^{169}$ The operation of these exogenous forces draws our attention back towards the question of the Europeanisation of citizenship in the new states of south East Europe, and especially the limitations that have resulted from the stalled enlargement process. Jelena Džankić and Soeren Keil argue that the process of Europeanisation in contested states encounters particular sensitivities around issues of sovereignty, to an extent that was not the case during previous enlargement rounds. ${ }^{170}$

Right from the beginning of the post-Yugoslav story, exogenous forces have been present, but not always been enabling. For example, after 1991 many of the citizens of the new states no longer enjoyed freedom of travel, and in many cases these restrictions lasted until Schengen visa liberalisation at the end of the 2000s. Here we already have an example of de-Europeanisation by denial. As part of a pathway to accession, Schengen visa liberalisation was achieved in 2009 and 2010 for the citizens of all the states apart from Kosovo. To achieve this, those states were forced to follow a strict pathway of conditionality, involving extensive national legislative adjustments in areas such as non-discrimination law and immigration law, even though no pathway to accession has yet been made visible. ${ }^{171}$ Perhaps the starkest example was Serbia which was required to distinguish between different groups of citizens in order to seek to ensure that Kosovans (including Kosovan Serbs) were not included in the visa liberalisation. ${ }^{172}$ Kosovans, of course, still require visas just to visit other parts of what was once the same country, and until recently struggled even to gain access at all to the territory of Serbia and Bosnia and Herzegovina, which do not recognise its existence. Meanwhile, the UK and Ireland - not part of the Schengen zone - continue to require that the citizens of all of the Western Balkan states obtain visas prior to travel. But Schengen visa liberalisation in turn has fostered flows of people and behaviours that some of the Member States have found to be problematic, such as overstaying the three months during which these groups are allowed to stay visa-free. ${ }^{173}$ The opportunity to move freely for the short term, but not to work or to settle, has highlighted economic inequalities between those states and the wealthier parts of the EU, as well as

166 E Sarajlić, 'Conceptualising citizenship regime(s) in post-Dayton Bosnia and Herzegovina', in Shaw and Štiks above n152, 83-97.

167 See above Shaw n152.

168 L Spaskovska, "The fractured "we” and the ethno-national "I” - the Macedonian citizenship framework', in Shaw and Štiks above n152, 99-112.

169 G Krasniqi, 'Overlapping jurisdictions, disputed territory, unsettled state: the perplexing case of citizenship in Kosovo', in Shaw and Štiks above n152, 69-82.

170 J Džankić and S Keil, 'The Europeanisation of Contested States: Comparing Bosnia and Herzegovina, Macedonia and Montenegro' in J Džankić et al (eds), The Europeanisation of the Western Balkans, New Perspectives on South-East Europe (Palgrave, London, 2018) 181-206. S Kacarska, 'Losing the rights along the way: The EU-Western Balkans visa liberalisation', (2015) 16 European Politics and Society 363-378. J Vasiljević, 'Imagining and managing the nation: tracing citizenship policies in Serbia', in Shaw and Štiks above n152. at 48. Kacarska, above n171. 
pinpointing the effects of economic and social exclusion operating within those states, creating effective underclasses such as the Roma (as a transnational group) or

Kosovans, who do not enjoy visa liberalisation and have the lowest per capita income in the region. ${ }^{174}$ In other words, it replicates the image of the Europe of many citizenships.

At the same time, during 2015 and 2016, the so-called 'Balkan route' became a major corridor and entry point to the European Union / Schengen area and the Member States of persons seeking refuge from Syria, Iraq, Libya, Afghanistan and other states experiencing conflict of various kinds. ${ }^{175}$ This has led to an increased securitisation of the Schengen border in that region and an outsourcing of securitisation to non-Schengen states. ${ }^{176}$ Moreover, the continuing presence of large numbers of refugees on their territories has posed challenges to societies that themselves are struggling with economic growth, social cohesion, political stability and ineffective governmental institutions.

In February 2018, there was a major relaunch of efforts to achieve enlargement, offering Serbia and Montenegro prospects for membership in 2025. ${ }^{177}$ It remains to be seen whether this process will lead to new progress towards enlargement for those two countries, or whether the name agreement between Greece and what is now the Republic of North Macedonia, which facilitated rapid NATO accession, will open up the route to EU membership. ${ }^{178}$ Despite the best efforts of those states holding the Presidency of the Council of Ministers - notably Romania in the first part of 2019 which has a clear regional interest in the issue - there is little sign that Western Balkan enlargement will become a priority for the Member States. It is clear that in comparison to the period 1992-2007, during which the institutionalisation of enlargement processes within the European Commission may have enhanced prospects for membership and for Europeanisation more generally (and especially for the benefit of the wider region of Central and Eastern Europe from which 11 countries acceded between 2004 and 2013), that the re-nationalisation of many aspects of the Western Balkans enlargement process has created a different dynamic. ${ }^{179}$ There is a significant gap between the rhetoric which recognises the Western Balkan countries as European, and thus their citizens as fellow Europeans, and the delivery of concrete steps towards enlargement. Not all of this can be attributed to the failings of the governments of the candidate countries.

The denial of accession has an intense impact for two reasons: first, the denial of Union citizenship limits the life chances of the citizens of those states; and second, there are knock-on effects of stalled enlargement on national citizenship regimes as a result of the responses of individual citizens. Pre-accession agreements to facilitate travel through

174 J Sardelić, 'The position and agency of the 'irregularized': Romani migrants as European semicitizens', (2017) 37 Politics 332-346.

$175 \mathrm{~J}$ Sardelić, From temporary protection to transit migration: responses to refugee crises along the Western Balkan route, EUI Working Paper, RSCAS 2017/35; C Minca et al, 'Managing the "Refugee Crisis” along the Balkan Route: Field Notes from Serbia’ in Menjívar et al above n31. D Župarić-Iljić and M Valenta, "Refugee Crisis" in the Southeastern European Countries: The Rise and Fall of the Balkan Corridor' in Menjívar et al above n31.

177 Commission Communication, A credible enlargement perspective for and enhanced EU engagement with the Western Balkans, COM(2018) 65, 6 February 2018. E Fouéré, The Greek-Macedonian name agreement - Promoting Reconciliation in the Western Balkans, CEPS Commentary, 29 January 2019.

179 Hillion above n14; F Bieber, 'Conclusion: Rethinking Europeanisation', in Džankić et al above n170, 237-246. 
visa liberalisation (or 'roadmaps' to visa liberalisation in the case of Kosovo) are not adequate substitutes for full free movement rights and the application of the nondiscrimination principle. Yet already, for any such advantages to be granted, accession states have to make substantial internal adjustments. Of course, Union citizenship does follow eventual accession, but extended transitional regimes and delayed access to labour markets and, especially, welfare regimes can render even this status contingent and partial, as Slovenians and Croatians in the region can attest. ${ }^{180}$ It is clear that denial of accession is at least partly about the denial of free movement and labour market access. Moreover, the legal texts governing accession and transition are often complex and require interpretation by the CJEU, rendering the law intransparent and inaccessible. Yet again, the image of the many citizenships of Europe comes to the fore. Elsewhere, the few incentives held out to the citizens of those prospective Member States to remain hopeful and optimistic are largely symbolic, such as the prospect of the abolition of roaming charges or the rollout of broadband across the region. ${ }^{181}$

Pushed into the periphery and into a relationship of continuing dependency by the $\mathrm{EU},{ }^{182}$ the situation in the Balkans contributes to complicating any common notions of 'Europe'. ${ }^{183}$ These countries retain their historic status as borderlands, a situation reinforced by the character and events of the so-called migrant crisis, when the western Balkans became one of the most important routes for entry into the EU. ${ }^{184}$ Reactions to that route, and the work done to close it, gave more meaning than ever to the idea of 'Fortress Europe', with much of the Balkans outside and subject to EU and national immigration laws. As a result, citizens in Western Balkan states have become increasingly disillusioned and disinterested, both in respect of their own state institutions, which are seen as ineffective ${ }^{185}$ and also in respect of the EU, its institutions and its Member States. ${ }^{186}$ Some have suggested that in Serbia, for example, Europeanisation has gone into reverse. ${ }^{187}$ Success stories such as the compromise reached between Greece and FYROM to rename the latter 'North Macedonia', with a view to freeing up NATO accession and eventual EU accession, are few and far between. ${ }^{188}$ Certainly Euroscepticism is on the rise, both in terms of the rise of parties trading in nationalist, Eurosceptic and 'anti-Western' ideas ${ }^{189}$ and in terms of a general weariness about the methods and approach of the EU and its Member States. ${ }^{190}$

\footnotetext{
180 P Dwyer et al, 'The impact of conditionality on the welfare rights of EU migrants in the UK', (2019) 47 Policy and Politics 133-50.

181 'EU-Western Balkans summit: improving connectivity and security in the region', European Commission Press Release, IP/18/3821, 17 May 2018.

182 Baker, above n9.

183 S Horvat and I Štiks (eds), Welcome to the desert of post-socialism radical politics after Yugoslavia (Verso Books, London, 2015). J Greenberg and I Spasić, 'Beyond East and West: Solidarity politics and the absent/present State in the Balkans’, (2017) 76 Slavic Review 315-326.

185 Greenberg and Spasić, above n184.

186 On attitudes to EU membership and accession see the data collected on the Balkan Public Barometer: available at <https://www.rcc.int/seeds/results/2/balkan-opinion-barometer $>$ and $<$ https://www.rcc.int/seeds/results/2/balkan-opinion-barometer>. A Castaldo and A Pinna, 'De-Europeanization in the Balkans. Media freedom in post-Milošević Serbia’, (2018) 19 European Politics and Society 264-281.

See Fouéré above n178.

M Stojić, Party Responses to the EU in the Western Balkans (Palgrave Macmillan, Cham, 2018). Belloni, above n22.
} 
One consequence of this situation has been an extensive deflection of those for whom this is possible into other citizenships, just as has been happening with the case of Brexit. Those with more than a single citizenship, or citizenship opportunity, have found ways to swerve some of the implications of stalled enlargement. As with Brexit, such a 'compensatory citizenship' can make up for the weakness, or perceived weakness, of the primary citizenship. ${ }^{191}$

The routes followed are many and various, with opportunities often arising from the stance of the target state in relation to kin minorities in neighbouring states. Hungary has made it particularly easy for non-residents who can demonstrate Hungarian ethnicity to acquire citizenship, applying very few conditions. This has been attractive in the Serbian region of Vojvodina where there is a substantial Hungarian diaspora. ${ }^{192}$ These actions have shored up the status of the governing party. The situation is similar for Bosnian Croats, who can easily access Croatian citizenship, as well as the right to vote in Croatia and Croatian welfare benefits. ${ }^{193}$ Macedonians may be able to access Bulgarian citizenship. ${ }^{194}$ Albanian citizenship is relatively easy for Kosovan citizens to obtain, not least because of continuing Albanian visions of a 'greater Albania' incorporating Kosovo. Kosovans (ethnic Albanians as well as ethnic Serbs) may also seek to acquire Serbian citizenship, despite Kosovo's secession from Serbia and the obstacles that the EU has placed in the way of Kosovo domiciled Serbian citizens (including ethnic Serbs) from benefitting from visa liberalisation. Either way, for citizens of Europe's most excluded state, these options may sometimes offer improvements in terms of freedom to travel.

Finding a second citizenship within the region is often less about affinity or emotional attachment, and more about 'trading up'. Where these target states are themselves EU Member States giving access to Union citizenship, this raises the same questions that the European Commission has been raising about preferential access to citizenship for investors, although in this case it is preferential citizenship for ethnic kin. ${ }^{195}$ If Member States maintain citizenship regimes which are open - whether to investors or to ethnic kin - they could well also be exploiting the attractiveness of Union citizenship to benefit themselves in some way. Moreover, it may have effects on the citizenship regime out of which the trade is made, in terms of hollowing it out, if very substantial numbers of citizens become dual citizens. It casts doubt, for example, upon exclusivity of allegiance to the state. This is particularly clear in the case of Bosnia and Herzegovina, where it is only one ethnic group - the so-called Bosniaks - who cannot point to a co-ethnic 'parent' country. There may also be a distorting impact upon the

\footnotetext{
$191 \quad$ Harpaz above n117.

192 J Tóth, 'The curious case of Hungary: why the naturalisation rate does not always show how inclusive a country is', GlobalCIT Blog, 3 January 2018, available at: <http://globalcit.eu/thecurious-case-of-hungary-why-the-naturalisation-rate-does-not-always-show-how-inclusive-acountry-is/>; S Pogonyi, 'The passport as means of identity management: making and unmaking ethnic boundaries through citizenship’, (2018) Journal of Ethnic and Migration Studies, DOI: 10.1080/1369183X.2018.1440493. A recent report about numbers of migrants to Croatia contains a reminder that those coming from Bosnia are often likely to have Croatian citizenship already so will not count in those figures: ‘43,000 People Moved to Croatia in 2018, Mostly from Bosnia and Serbia', Total Croatia News, 4 February 2019, available at: <https://www.total-croatianews.com/politics/33961-croatia-in-2018> V Neofotistos, ‘Bulgarian Passports, Macedonian Identity’, (2009) 25 Anthropology Today 1922. See above the text at n74 and following.
} 
citizenship regime of the target state, although in some cases - as with Hungary - these effects may be sought by the government, if it considers that allocating citizenship and voting rights (without prior residence) to the 'diaspora' is liable to profit one particular political party and to enable it to hold on to power. ${ }^{196}$ Similar reflections would apply in the case of the openness of Croatia's citizenship regime to ethnic Croats from Bosnia and Herzegovina.

In the Western Balkans it is rarely economic privilege alone that opens the doors to a second citizenship, but more often the happenstance of birth. The fact that these strategies are viewed as both acceptable and indeed desirable by many lends substance to Ayelet Shachar's longstanding argument that one of the most important dimensions of distributive justice on a global scale remains the birthright citizenship allocation rules of states, which give rise to substantial and enduring structural inequality. ${ }^{197}$ Market access flows from having a Union citizenship, rather than just one from the Western Balkans and from this will in turn flow economic advantage. Combined with internal structures of exclusion, such as those which often restrict the access of the Roma to formal identity documentation, the happenstance of where you are born, and who your ancestors were, will then reinforce old and new vulnerabilities and vectors of privilege and inequality. It gives substance to the image of a region of many citizenships, and of uneven citizenship opportunities for different groups.

For those who have already left the region for work or family reasons, or as refugees or displaced persons during the 1990s, there is unlikely to be much hesitation in seeking naturalisation once the conditions for this in the host state are satisfied. Figures show that Albanians were amongst the main recipients of Union citizenship in 2017, with Italy and Greece being the two countries where they are most likely to naturalise. ${ }^{198}$ Serbia and Kosovo are also in the top 30 'receiving' nationalities. Well-trodden routes also include those carrying Bosnian, Serbian and Kosovan migrants to Austrian citizenship, even though this will require the renunciation of their origin state citizenships because of Austria's continued resistance to dual citizenship. ${ }^{199}$ It should be noted that most states across the region are open to dual citizenship, with the exception of Montenegro and Bosnia and Herzegovina (to a lesser extent). ${ }^{200}$ In fact, the practice of compensatory citizenship generally depends upon the widespread liberalisation of dual citizenship since the second world war.

One important point that emerges from this story of stalled and perhaps failed enlargement is that the teleology of an ever wider and deeper Union with transformative effects - with consequential impacts upon citizens - is now in deep trouble. ${ }^{201}$ As a

196 B Majtényi et al, “'Only Fidesz” - Minority Electoral Law in Hungary’, Verfassungsblog, 31 March 2018 available at: <https://verfassungsblog.de/only-fidesz-electoral-law-in-hungary/>. A Shachar, The birthright lottery: Citizenship and global inequality (Harvard University Press, Cambridge, 2009).

198 For further details see, ‘Acquisition of Citizenship Statistics’, Eurostat Statistics Explained, March 2019, available at: <https://ec.europa.eu/eurostat/statisticsexplained/index.php/Acquisition_of_citizenship_statistics>. 'Austrian Citizenship Awarded to Nearly 10,000 Foreigners', Vindobona, 28 February 2019, $<$ https://www.vindobona.org/article/austrian-citizenship-awarded-to-nearly-10-000-foreigners>. See Džankić above n157.

201 J Woelk, 'From Enlargement Perspective to "Waiting for Godot”? Has the EU Lost Its Transformative Power in the Balkans?' in L Antoniolli et al (eds), Highs and Lows of European Integration (Springer International Publishing, Cham, 2019) 27-47. 
process, Europeanisation in the Western Balkans has proved to be hesitant and ambiguous, and perhaps reversible. Holding out the possibility of EU membership has contributed to semi-Europeanised citizenship regimes in those states, but part of that Europeanisation process has been horizontal in character, as individual actions have contributed to a progressively closer entwining of different national citizenship regimes in constellations, both within the region and across its external boundaries. The 'dual citizens', of various kinds, find themselves often in a better position to access the benefits of EU free movement and Union citizenship. In that respect, we can see a Europe of many citizenships, and diverse types of (European) non-citizenship, as many of the 'left behind' citizens of the former Yugoslav states, and the formerly isolated Albania, struggle to overcome the heritage of their respective histories.

\section{Conclusions: (semi-)Europeanised citizenship in a loose and messy Union}

In this article, the transformation of citizenship regimes in the European constitutional space has been used as a test case through which to explore the processes of integration and disintegration or 'troubled membership' which are occurring across the north western and south eastern borders of the European Union. In this brief conclusion, I want to sum up the main findings and link the case studies of citizenship governance back to the broader questions of constitutionalism and constitutionalisation in the europolity. There are pragmatic links between Brexit and stalled enlargement, as scholars have noted. Brexit risks diverting attention away from the issue of enlargement. ${ }^{202}$ But it is clear that the parallels go beyond such narrow points to reflect also the many faces of citizenship, as well a Europe of many citizenships. It is interesting to see the various dynamics between the EU institutions and the Member States in relation to the two cases. A striking degree of togetherness has been demonstrated by the EU27 in relation to Brexit. As Member States reassert control over enlargement, there has been a noticeable splintering of approaches, reflecting the divergent interests of the states. Yet in the area of Brexit it is clear that many of the citizenship-related dynamics are still inevitably controlled and dealt with by the Member States, and not by the EU institutions, because national citizenship is a creature of national law.

If Brexit is a failure of the cosmopolitan vision, ${ }^{203}$ then there are parallels in the 'failure of vision' which relates also to the refusal of enlargement on the grounds that the Western Balkans are just too, well, 'Balkan' to be 'proper' members of the EU. 'Europeanness' seems to be a very unstable concept. ${ }^{204}$ On both sides, there seem to be strongly racialised discourses in place. ${ }^{205}$ It might be tempting to point to 'EU intransigence' in both cases, and to claim that the citizenship consequences of Brexit and the denial of Union citizenship in the case of stalled enlargement are a result of the failure of the EU and its Member States to reform free movement and thus to make EU

202 R Belloni and M Brunazzo, “After "Brexit”: The Western Balkans in the European Waiting Room’, (2017) European Review of International Studies 1, 21-38.

203 C Calhoun, 'Populism, Nationalism and Brexit', W Outhwaite (ed), Brexit: Sociological Responses (Anthem Press, London, 2017) 57-76.

$204 \quad$ F Ammaturo, 'Europe and whiteness: Challenges to European identity and European citizenship in light of Brexit and the "refugees/migrants crisis"', (2018) European Journal of Social Theory DOI: $10.1177 / 1368431018783318$.

205 G Bhambra, 'Locating Brexit in the Pragmatics of Race, Citizenship and Empire’, in Outhwaite, above n203, 91-99; K Burrell, 'Brexit, race and migration’ (2019) 37 Environment and Planning C: Politics and Space 3-40; K Koram, 'Britain’s Blindness', Dissent Magazine, 6 February 2019, available at <https://www.dissentmagazine.org/online_articles/britains-brexit-blindness>. 
membership more attractive for UK voters who fear immigration and more accessible to a set of countries from south east Europe, which are otherwise seen as triggers for excessive immigration if they are allowed into the club. There are fraught politics on both sides, although only in the case of Brexit has it become clear that there might be 'cliff edge' problems for citizens in the event of both the threat and the actuality of a no deal Brexit. With the Western Balkans as a whole, just as with many of the conflicts within the region, so the relations between those states and the EU seem frozen and incapable of being moved forward.

After Brexit, EU27 citizens now face the prospect of dealing with the UK's so-called hostile environment for illegal immigrants and UK citizens face uncertain futures under 27 different legal regimes. The movement of people across the boundaries of Union citizenship highlights the sharp distinction between the strong personal freedoms of 'free movement' and the restrictions and discretionary measures of 'immigration law'. 'Fortress Britain' comes with costs, as it may also make UK citizens the subjects of Fortress Europe. These are the challenges already faced by those from the Western Balkans who try to travel or settle in the UK, but Brexit will bring some of these costs much closer to 'home', shaking up the established 'citizenship constellations' formed around the core of the UK's EU membership over 40 years.

Brexit and stalled enlargement help to show how Union citizenship remains a partial, differentiated and conditional status and yet it is also a potential pathway to greater personal and social freedom and a status which retains some promise of equality for the future. It is clear that the deflection strategies of individuals 'escaping' Brexit and stalled enlargement present Union citizenship as an attractive destination or stopping point. But at the same time, those strategies place question marks over the character of Union citizenship, if it is to be understood as an instrumental rather than a constitutional status.

But beyond this, there may also be other paradoxical and complex effects which arise as a result of the collapse, neglect or denial, of Europeanisation in relation to the governance of citizenship across the fuzzy outer borders of the EU. These effects could see a set of common interests emerging across a range of actors, including citizens of excluded states, citizens of new Member States subject to transitional regimes, third country national family members of EU citizens and 'static' EU citizens, none of whom are feel fully valorised within the predominantly economistic conception of 'membership' under EU law. Members of all of these groups may contest, for example, the model of equality being used to justify the current conception of Union citizenship, favouring as it does multiple over singular forms of membership. Some may welcome the disruptive forces of troubled membership, whilst fearing a potential loss of rights if legal changes are effected in a disorderly manner, or without regard to their interests. But others reject any departure from the status quo as creating first and foremost new and unwarranted insecurities. From this we can see that troubled membership may not so much be an anomaly thrown up by the sorts of challenges that have arisen in the north west or south east of the European continent, but rather an embedded feature of a multi-level architecture for citizenship governance, such as that observed in this article.

At the outset of this article, we noted that membership of the European Union mandated the sharing of sovereignty in some areas amongst states, as well as the involvement of supranational institutions endowed with competences protected under the rule-based 
system of the Treaties. This idea embodies a powerful and neat idea of supranational integration which is rarely completely reflected in practice. Recent years have seen not just the disruptive elements of Brexit and stalled enlargement, but also instances of democratic backsliding amongst the (continuing) Member States. In all of these cases, issues of (national) sovereignty have played a role, as the limits of the Union's inchoate and often contested constitution come clearly into view. The ebbs and flows of Europeanisation across the EU citizenship regime, as well as those of the current, future and possibly withdrawing Member States, turn many of these ideas from theoretical commitment to principles such as the rule of law, democracy and fundamental rights into live issues of inclusion and exclusion across the boundaries of the EU. 